\title{
Made in America?: Immigrant Occupational Mobility in the First Half of the Twentieth Century
}

\author{
By \\ Peter Catron \\ Department of Sociology \\ University of California, Los Angeles \\ pcatron@ucla.edu \\ Pre-print version \\ Published in the American Journal of Sociology 122(2): 325-78
}

\begin{abstract}
:
Assimilation research largely assumes that Southern and Eastern European immigrants achieved assimilation due to job ladders within manufacturing firms in the first half of the twentieth century. But this literature has never tested these claims and often acknowledges that little is known about whether Italians and Slavs experienced upward mobility. Did manufacturing allow for the upward advancement among European-origin groups? Using unique datasets containing employment histories in three manufacturing companies - A.M. Byers Company, PullmanStandard Manufacturing, and Ford Motor Company - between 1900 and 1950, this article is the first to analyze occupational mobility within factories among European-origin groups. Results suggest that organizational structures within firms through the formation of internal labor markets did little to counter or prevent other forces that kept migrants from achieving upward mobility. Migrants ended their careers within firms where they began - positions at the bottom of the occupational hierarchy - which runs contrary to assimilation research.
\end{abstract}




\section{Made in America?: Immigrant Occupational Mobility in the First Half of the Twentieth Century}

"In the thirties if you was an Irishman you would get the heating job...but if you were a Pollock or a Slovak you couldn't get the God damned job." - Chester P., A.M. Byers Company (cited in Santos 1984: 78)

Before its postwar golden age of the 1950s and 60s, manufacturing was one of the largest and important sectors in the United States. In any given year between 1900 and 1950, thirty to forty percent of all nonfarm employees held jobs in manufacturing industries (Lebergott 1964). At the same time, a wave of immigrants from Southern, Central, and Eastern Europe descended on the industrialized North. These European migrants' rural origin, lack of previous experience and special skills, and weak attachment to the labor force helped fill the large demand for unskilled laborers that manufacturing required (Hutchinson 1956). The proliferation of highly paid skilled and managerial work in this sector offered a potential avenue for socioeconomic advancement among unskilled immigrants. However, organizational structures within firms did not favor upward mobility for unprivileged groups (Doeringer and Piore 1971). While Southern, Central, and Eastern European immigrants eventually 'made it' in America (Lieberson 1980;

Waters 1990), surprisingly little is known about whether Italians and Slavs experienced upward mobility at the turn of the twentieth century and, if so, to what extent, how, and why (Waldinger 2007).

That still unexplored issue is the focus of this paper: Did manufacturing allow for the upward advancement among Southern and Eastern European-origin groups? To answer this question, I rely on unique datasets that contain longitudinal worker histories from three manufacturing companies: A.M. Byers Company, Pullman-Standard Manufacturing, and Ford Motor Company from 1900 to 1950. Unlike scholarship on the historical relationship between immigrants and manufacturing that relies on census data, I analyze occupational mobility over 
large portions of an individual's working history. First, I investigate occupational mobility among different European-origin immigrant groups vis-à-vis the native-born. These analyses are informed by theories of organizational sociology and in particular the role internal labor markets influenced mobility among European-origin groups. Second, I analyze the specific mechanisms that allowed Southern and Eastern European immigrants to move up (or down) the occupational hierarchy in manufacturing plants. These analyses challenge assimilation hypotheses that stress manufacturing as the key to Southern and Eastern European immigrant success in the first half of the twentieth century (e.g., Alba and Nee 2003; Portes and Zhou 1993).

\section{Immigrants, Manufacturing, and Upward Mobility}

The onset of the $20^{\text {th }}$ century proved inauspicious for immigrant populations in the United States. The influx of Southern, Central, and Eastern European immigrants (hereafter SCEE immigrants) provoked worries that a docile and vulnerable working population would have a balkanizing effect on the native working class. Unlike their protestant predecessors from Western Europe who were largely viewed as contributors to America's economic advantage and system of values (with the exception of the Irish), the Catholic, Eastern Orthodox, and Jewish migrants who came from rural areas were treated with suspicion by unionists and the native-born (Lane 1987). SCEE immigrants were generally poor and compelled to take low-skilled and seasonal jobs throughout industrialized cities. Even though the economy was expanding rapidly at the time, the large supply of manual workers increased competition for laborer jobs (Lane 1987). The crowding of unskilled workers led to labor and ethnic conflicts that erupted with the growth of an immigrant and black workforce in the industrialized North (Olzak 1989). However, employers preferred hiring newcomers since ethnic competition reduces worker solidarity and 
prevailing wage standards (Hatton and Williamson 1998; Lichtenstein 2002; but see Carter and Sutch 1998; Hirschman and Mogford 2009). Consequently, native-born unionists in the American Federation of Labor (AFL) and other antiforeigner groups organized and lobbied at the federal level successfully to restrict future immigration flows (Tichenor 2002).

Despite their humble beginnings, however, SCEE immigrants became indistinguishable from their Western European predecessors over time (Lieberson and Waters 1988). The prevailing approaches to assimilation offer a deterministic view of the industrial structure in the first half of the twentieth century. In contending that job ladders in manufacturing allowed for upward mobility, proponents of both segmented and neo-assimilation theory invoke a period effect. In the segmented assimilation approach, the most dominant account, shared European ancestry allowed immigrants and their descendants to bypass discrimination and benefit from the buildup of craft and managerial work in manufacturing (Portes and Rumbaut 2001). The neoassimilation approach argues that assimilation was "based on historically contingent periods of economic expansion that allowed immigrants of peasant origin with few work skills of relevance in an urban, industrial economy...to gain a foothold through steady employment, often in manufacturing sectors to begin with" (Alba and Nee 2003: 134-135). Although the most important period for this framework is between 1930 and 1970 when the second generation came of working age, and they admit that some migrant groups did not use manufacturing to achieve upward mobility, the starting positions of different groups depended on their sectoral distribution - whether more or less heavily represented in manufacturing and its different branches - and on their positions within the occupational hierarchy. Since SCEE immigrants were overrepresented in all manufacturing sectors and especially in heavy manufacturing (Hirschman and Mogford 2009), the first generation experience within manufacturing firms inevitably had to affect the 
starting position of the second generation during the most critical period of the neo-assimilation approach.

While there are subtle differences between segmented and neo-assimilation regarding the specific mechanisms they emphasize (see Waldinger 2007), proponents of either framework have never tested their claims. Indeed, the centrality of manufacturing in producing assimilation runs contrary to historical evidence (e.g., Bodner 1985; Bodner et al. 1982; Morawska 1985;

Perlmann 2005; Perlmann and Waldinger 1996; Waldinger 2007). Further, these frameworks do not consider how organizational structures patterned mobility for the first generation.

Migrants who came to the United States faced negative circumstances including a peasant origin, scientific racism, employer discrimination, and other barriers that would have limited prospects for upward movement. For upward mobility to occur within manufacturing firms as assimilationists contend, therefore, organizational structures would have to override these forces. However, structural arrangements of firm promotion policies pattern mobility by creating discontinuities in the rate of promotion among individuals and groups (Spilerman and Petersen 1999). They may do this at the point of hire, job ladders within the firm, and through departures. Indeed, there is a large literature that shows how organizational structures play a key role in generating and perpetuating inequality in employment outcomes among different groups (see, e.g., Baron and Bielby 1980; Castilla 2008; Fernandez and Sosa 2005; Petersen and Saporta 2004; Petersen and Spilerman 1990). In the first half of the twentieth century, internal labor market structures were developed that explicitly allowed for upward mobility within firms that would have counteracted the negative contexts experienced by SCEE groups (Doeringer and 
Piore 1971). However, access to favorable promotion lines within these organizational structures was often segmented that made upward mobility unlikely for unprivileged groups.

\section{Organizational Perspectives to Socioeconomic Mobility and Immigration}

Internal labor market structures (hereafter ILMs) provide definite occupation promotion lines within administrative units, such as a manufacturing plant (Doeringer and Piore 1971). Whereas firms without ILMs rarely promoted workers from within in the early twentieth century (Jacoby 1984), firms that developed ILMs provide the most favorable avenue for upward mobility within an individual plant. Within ILMs, senior-level jobs are filled from within the firm where employees move up job ladders to enter craft and managerial positions.

ILMs emerged in the early twentieth century as a result of both worker and personnel managerial responses to the 'drive system' that sought to increase production without considering worker rights (Elbaum 1984; Jacoby 1984). In some firms, the workers' response to the drive system was to organize into powerful craft unions that determined the rules and procedures of the plant (Elbaum 1984). Management had little choice but to accept the procedures implemented by craft unions because workers made claims based on their on-the-job skill and its relationship to product quality (Applebaum 1981; Kimeldorf 2013). Craft unions then implemented ladders for socioeconomic mobility that would favor some occupations while excluding others. Craft unions and occupational groups would hoard opportunities for their members, who were largely native-born WASPs, relegating nonunion workers to unprivileged, often laborer positions, within the firm. Personnel departments also favored ILMs as a response to the large number of quits associated with the drive system (Jacoby 1984, 1997). As the cost of replacing workers increased - especially during WWI - personnel departments were created to 
handle increased bureaucratization and to develop rewards for loyal workers who stayed in the firm by promoting them to higher positions. However, foremen maintained considerable power in who entered their department and personnel departments often resorted to promoting native white workers who were viewed as acceptable for skilled work leaving SCEE migrants and black workers in departments with little opportunity for upward advancement (Jacoby 1984; Nelson 1975; Foote et al. 2003).

Examinations of ILMs indicate that occupations and careers are used as a form of social control (Fligstein and Fernandez 1988). Entry into an ILMs is controlled where different entry portals lead to distinct career paths within the firm. Some entry portals allow for upward mobility while others do not. Upward mobility on any ladder, however, often relies on obtaining firm-specific-forms-of-capital, such as on-the-job training and an understanding of networks that provide crucial information (Althauser 1989). This on-the-job learning is informal and depends on social interactions between workers over time (Bailey and Waldinger 1991). However, a core tenet of ILMs is their ability to segment the labor market within a firm (Doeringer and Piore 1971; Doeringer 1986). Submarkets are developed within a firm where rules of promotion and lay-off procedures favor certain occupational groups, while simultaneously harming other occupational groups. The unprivileged occupations held little possibility for occupational mobility, and were disproportionately held by ethnic minorities, women, and the recently unemployed (Stinchcombe 1990). Thus, while there were many craft and managerial positions in manufacturing, as assimilationists argue, SCEE immigrants lacked access to occupations at the median and above according to ILMs theories. Of course, ILMs made for greater inequality among workers pre-industrial unionization and lesser inequality post-industrial unionization. ${ }^{1}$

\footnotetext{
${ }^{1}$ Industrial unions organized the entire workplace as opposed to craft unions mentioned above that organized workers along a particular craft or trade.
} 
These unionization effects, however, were most likely felt by the second generation who largely came of working age during or after the Wagner Act of 1935.

The role of external labor markets is also important when determining occupational mobility within firms because it provides workers with employment opportunities outside of the internal labor market that may or may not provide better chances for advancement. Workers have the option to either remain within the firm and accept the prospects of future advancement or leave for employment (or potentially non-employment) elsewhere (Petersen and Spilerman 1990). That is, a voluntary departure (done for either career or non-career reasons as described below) depends on the structure of opportunity in an organization and the structure of opportunities in the local labor market. If individuals and groups find employment in the firm, but are queuing for better jobs outside the firm, their socioeconomic mobility in the firm may be limited. However, if no such queues exist, groups may be more likely to invest in their workplace capital to try and get ahead within the firm. That is, occupational mobility is not only structured by movement within the firm, but is also affected by the structuring of career opportunities outside the firm (Petersen and Spilerman 1990). Thus voluntary departures from a firm depends on the structure of opportunity faced in an organization and the structure of opportunities in the local labor market which is often defined by geography.

Geographical disparities in settlement patterns influenced job market opportunities at the turn of the twentieth century as the type of manufacturing occupations available differed from the Northeast to the Midwest. As Waldinger (2007) notes, Italians generally settled in the MidAtlantic and Northeast, with a concentration of employment in light manufacturing, services, and other jobs related to the highly diversified economies of cities like New York, Philadelphia, and Boston. Poles, on the other hand, generally settled in the Midwest, with its concentration of 
heavy manufacturing firms (and later, CIO strongholds), and where cities had much more specialized economies. Locational configurations are associated with different patterns of wage determination and status attainment: e.g., living in the Midwest had a positive impact on earnings but a negative impact on socioeconomic status, reflecting the low status of occupations in heavy manufacturing in Waldinger's study. While large manufacturing firms developed internal labor markets, employers looked outside the firm to fill senior-level jobs in industries such as construction, services, and light manufacturing. The interlocking of ethnicity and institutions took a different form in these settings and may have allowed for Italians and other groups who settled in cities with diverse economies to find upward mobility without relying on the heavy factory sector (Abramitzky, Boustan, and Eriksson 2014; Waldinger 2007) (see Bailey and Waldinger 1991 for a discussion on the role of external labor markets and mobility). As organizational structures within the firm and local community defined mobility among SCEE migrants, other parts of the immigrant experience often interacted with these structures that enhanced or reduced mobility.

In the Age of Mass Migration, SCEE migrants often entered the United States as target earners who searched for wages that could allow them to invest in their homelands (Piore 1979). ${ }^{2}$ With identities in their sending communities, immigrants often accepted menial jobs in unprivileged positions since they held a short time horizon. However, instability was often a defining feature of these occupations that made immigrants prone to lay-offs, dangerous working conditions, etc. that would lead to less work and therefore less money (Piore 1979). As consumption increased, and disposable income decreased, immigrants' time horizon became longer. With little to no human capital accumulation (either from the sending country or the

\footnotetext{
${ }^{2}$ Some immigrant groups such as the Macedonian Bulgarians, however, entered the United States due to political oppression in their homeland as opposed to improving their impoverished state (Bodner 1977).
} 
receiving country), and a lack of social ties to the native-born to gain the necessary firm-specific capital, SCEE immigrants had little choice but to continue working in menial jobs within firms. The concentration of minorities in unprivileged occupations led many jobs to become stigmatized (such as "guido," "dago," "hunkie," or "bohunk" work) that made between-group interactions needed for informal training less likely for immigrant populations. That is, cultural understandings within firms allowed for a division of labor such that immigrants were thought to be the perfect workers for menial occupations that the native-born would not work (Fischer and Hout 2006).

Stigmatized work and stigmatized origin often overshadowed migrants' ability to find upward advancement in manufacturing (Morawska 1985). People who share common traits, such as a similar ethnic origin, will embed themselves into interlocking networks and activities with their co-ethnics that in turn shape aspirations and careers over time (Massey et al. 1987). Since newcomers often rely on their co-ethnic social networks to find employment, they will most likely concentrate in jobs where veteran migrants have already been established (Waldinger and Lichter 2003). This means that recent arrivals will likely find employment where longtenure immigrants work, which were at the bottom of the social stratification system in departments and occupations that lacked avenues for upward mobility.

The context of origin of immigrant groups likely matters given the diversity of migration streams, cultural understandings, and the level of economic development in sending communities. In the first half of the twentieth century, there was large heterogeneity in the level of industrialization and state building throughout Europe. Whereas Western Europe industrialized early, Southern and Eastern Europe industrialized late and were in the process of “catching up" (Gerschenkron 1962). Within countries, different economic possibilities exist at 
different historical junctures, which in turn socializes individuals within these countries toward certain predispositions to the workforce (Inglehart and Baker 2000). Migrants import with them these predispositions that may affect their ability to achieve upward social mobility. Immigrants who come from countries with little to no exposure to manufacturing jobs and life in urban areas may fare worse in manufacturing plants in the United States than individuals who come from industrialized urban communities. Indeed, this is corroborated in empirical research where immigrants who originated from industrialized countries entered the labor market at similar positions as native workers and immigrants from poorer countries performed worse during this period (Abramitzky et al. 2014).

The dominant accounts of internal labor market and assimilation theories lend themselves to different conclusions about the role manufacturing played for immigrants. Internal labor market theories predict that immigrants were hired at the bottom of the occupational hierarchy, were less likely to make upward occupational moves, and likely remained in the firm since employment prospects outside the firm were likely no better. Assimilation theories, however, have merely asserted that job ladders within firms allowed for upward advancement without detailing how this process occurs. However, they do predict that SCEE migrants eventually converge with native-born workers on employment outcomes. Although assimilation theories do not deny that immigrants likely started at the bottom of the occupational hierarchy, they do suggest that job ladders within firms allowed for equal or greater mobility. According to this view, immigrant workers will either be no less likely or more likely to experience upward occupational movements within the firm, all else equal. That is, if immigrants start at lower positions in the firm, they will be more likely to experience an upward move to achieve 
convergence with native white workers. On the other hand, if immigrants show no difference in starting position, then they will be neither more nor less likely to experience an upward move in the firm since they have already reached parity with native-born workers.

The remainder of this paper seeks to explore mobility at all points of workers' employment histories (job entry, upward and downward moves, quits) to understand whether immigrants experienced upward mobility. In addition to answering these hypotheses, this article analyzes specific mechanisms that allowed for upward advancement among European-origin groups within firms. In particular, it tests whether citizens are more likely to obtain better employment outcomes than non-citizens, whether immigrant groups who originate from less developed areas have worse employment outcomes than immigrant groups who originate from more developed areas, and how years in the US affect mobility.

\section{The A.M Byers, Pullman-Standard, and Ford Motor Company Data}

Data consist of longitudinal worker histories from three Northern manufacturing companies in the first half of the twentieth century: A.M. Byers Company, Pullman-Standard Car Manufacturing, and Ford Motor Company. The data were originally collected by Warren Whatley and Gavin Wright for a project on the racial policies of Northern employers before the Second World War. All files are publically available through the Inter-University Consortium for Political and Social Research (ICPSR). ${ }^{3}$

The A.M Byers Company, which began in 1863 and closed in 1969, manufactured highquality wrought-iron pipe and galvanized tube (Santos 1984). Whereas production in the iron and steel industry switched from wrought iron to steel once the low-cost Bessemer process became available, Byers resisted this change, as did many similarly situated companies, and

\footnotetext{
${ }^{3}$ The Byers files may be found at ICPSR 6359, Pullman at ICPSR 6351, and Ford at ICPSR 6352.
} 
continued to rely on skilled workers to make high-quality wrought iron (Ingham 1991). Byers developed lucrative niche markets by selling their tube to oil and gas, mining, and irrigation firms in the Southwest (Ingham 1991). Before 1930, skilled workers in Byers enjoyed the autonomous work that was afforded to them through craft union bargaining of the Sons of Vulcan and later the Amalgamated Association of Iron, Steel, and Tin Workers (Santos 1984). The company signed its first contract with the CIO-based Steel Workers Organizing Committee on May $5^{\text {th }}, 1937$. The data for A.M. Byers Company contain a stratified random sample of workers in Ambridge, Pennsylvania and the Southside of Pittsburgh between 1916 and 1952. The records, which are currently located in the Archive of Industrial Society at the University of Pittsburgh, were partitioned into consecutive strata of five records and one record was randomly selected from each stratum (Whatley and Wright 1995a). This produced a representative sample of 5,780 employees, which were then supplemented with an oversample of 1,218 black employees. The records contain histories of individual workers' employment with the company along with demographic information.

Pullman Palace Car Company, and much later Pullman-Standard Car Manufacturing Company, began in 1867 to build and operate sleeping cars for railways (Whatley and Wright 1995b). After the wildcat strike of 1894, which led to the creation of Labor Day as a federal holiday, Pullman split into several divisions of car works and repair shops (Hirsch 2003). So as to limit future labor unrest, Pullman sponsored the Great Migration of black workers from the South and later began experimenting with welfare capitalism (Hirsch 2003; Jacoby 1997). In the late 1930s, however, it became unionized by the United Steelworkers and in 1948 the company held a monopoly and was forced to split into separate companies. Pullman officially closed in 1981. The Pullman files, which are housed at the South Suburban Genealogical and Historical 
Society in South Holland, Illinois contain a stratified random sample on workers in Calumet, Illinois between the years 1902 and 1948. Every other box was selected from the Pullman archives and then the records were partitioned into consecutive strata of 40 records with one randomly selected personnel file pulled from each stratum. The sampling was then augmented with a black oversample, and another oversample of records after 1937, when education was recorded (Whatley and Wright 1995b). The final dataset includes the employment histories of 4,147 workers and contains similar worker histories as the Byers data.

Ford Motor Company, of course, is the car manufacturer that exists today. Ford placed a strong emphasis on the Americanization of its foreign-born workers - especially among Southern and Eastern Europeans. At the time, Henry Ford established a Sociology Department to remake the lives of immigrant workers. Only after immigrants could demonstrate proper home environments and middle class values would they qualify for the famous Five Dollar Day plan (Barrett 1992; Loizides 2007). This led to unique ethnic tensions between migrant groups and management in the company. The files from Ford contain worker histories of those who were employed after 1918 and who had left by 1947 . Since the files are sorted alphabetically, the sampling procedure began with a one-in-eight selection of boxes. Then every first and thirtieth record was chosen to provide a representative sample. A supplementary sample of black employees and two more supplementary samples of records with education information were then added. This led to 4,144 workers in the files. Workers in these files come from four major plants: the Rouge Plant (America's largest manufacturing plant), Highland Park (where Fordism began), Lincoln Motor Company (which was acquired in 1922), and the Willow Run plant located in Ypsilanti, Michigan. Willow Run began production in 1942 to build bombers during World War II (Whatley and Wright 1995c). There are also employee records for mine workers 
in northern Michigan and other workers employed by Ford operations throughout the state, which are omitted in the analyses below. All Ford operations were unionized in 1941.

The three companies kept detailed records of both demographic and job characteristics of individual workers over time. The demographic information includes age, gender, marital status, number of dependents, years of education, and race. It also includes variables that allow us to discriminate whether the worker was born in the US or another country. Further demographic information about immigrant workers was recorded such as descent, date of arrival in the US, country of citizenship, and English language ability at the time of hire. The job characteristics include the start and end date of each job, wage, occupation, department, and the reason for leaving.

To make the data more concrete, I present worker profiles from each dataset. The employee profiles present varying trajectories. For instance, the Polish worker in Byers entered the firm as a laborer and worked for less than a year before he quit for a "better job." He then returned at a laborer position five years later and worked until 1927 when he quit due to small wages. ${ }^{4}$ The Norwegian worker in Pullman experienced upward mobility, moving from a metal cleaner to a riveter, but his employment was short-lived since he entered the Marine Corp during WWII. Similarly the Maltese migrant in Ford started as a light press operator and then moved to a hydraulic press operator before he was laid off. He also experienced considerable wage mobility during his employment.

[INSERT TABLE 1 HERE]

\section{Case Selection}

\footnotetext{
${ }^{4}$ The 1939 Dictionary of Occupational Titles labels fagot makers, scale wheelers, and sand wheelers as laborer positions.
} 
While the preservation of these records makes examination of the employment profiles worthwhile in and of itself, the three case studies raise the question not only of how they compare to one another, but also to heavy manufacturing as a whole. Ford was an innovative giant in American industry that has continued to exist; Byers was a small, regionally based firm that was never at the cutting edge; and Pullman grew through acquiring smaller firms, eventually leading to a monopoly in railcar manufacturing. The factories controlled by these companies were also different sizes. Byers employed roughly 1,000 to 2,000 employees each year during this time (Santos 1984), while Pullman employed between 4,000 and 6,000 employees in 1900 (Nelson 1975). These factories, however, pale in comparison to the gargantuan factories of Ford where Rouge alone is estimated to have employed between 68,000 and 100,000 workers and Highland Park employed over 40,000 workers (Nelson 1975).

Nevertheless, ILMs were "invariably" set up in iron and steel industries through the bargaining of the Sons of Vulcan and the Amalgamated Association of Iron, Steel, and Tin Workers (Elbaum 1984). By association with these craft unions and industry, Byers was forced to adopt these bureaucratic structures. Indeed, job vacancies at higher level positions in the firm were filled by existing personnel (Santos 1984), which is consistent with ILMs. The job hierarchy within Byers also shows that native white workers and old-stock migrants were disproportionately working in skilled jobs while southern and eastern European immigrants worked in laborer positions. Due to the pressures of craft union workers described above, A.M. Byers allowed for promotion schemes set up by skilled workers that favored the native-born and old-stock migrants the most (Santos 1984).

The rapid expansion rapid expansion of Ford and Pullman factories, on the other hand, created numerous administrative difficulties that led to bureaucratization. Ford's personnel 
managers implemented many of the rules and procedures defined by internal labor markets around 1914 that promoted internal mobility within the firm (Jacoby 1984), and Pullman adopted similar structures in the late nineteenth century as a response to the wildcat strike in 1894 (Hirsch 2003). Both companies developed ILMs in order to undermine labor activity. For instance, managers in Pullman used "separate and unequal job ladders to pit workers against each other" and used racial/ethnic categories to place people into privileged and unprivileged ladders (Hirsch 2003: 15). All supervisors and managers in the company came up through the ranks. Pullman was one of the first companies to develop ILMs that afforded workers long careers with the company (Hirsch 2003). Ford developed a similar system using the same management practice of separating workers based on race/ethnicity that ultimately favored native-born white workers (Bonacich 1976). These three companies are therefore likely representative of firms that developed ILMs, but are not representative of firms without these structures. Manufacturing firms without ILMs, however, often did not have definite promotion lines within their firms (Jacoby 1984), which would make upward mobility of immigrants less likely in those types of firms than with firms with ILMs.

\section{Variables and Methods}

The personnel records described above are used for individuals who were in the companies as of the beginning dates of the data collection (1916 for Byers, 1902 for Pullman, and 1918 for Ford) or entered after the beginning date but before the ending date (1952 for Byers, 1948 for Pullman, and 1947 for Ford). Data are limited to men working in manufacturing plants described above. While women appear in the files, nearly two-thirds of their employment spells in each company corresponds to WWII. The war period was the only time heavy 
manufacturing had use for female labor (Milkman 1987). I also exclude the mine workers in the Ford files since the ethnic composition and structure of jobs likely differed than those in the factories.

The primary objective of this paper is to understand occupational mobility among immigrant workers within firms. Because these companies did not organize occupations into any hierarchy, nor, for that matter, use any standardized occupational coding system, it becomes necessary to match occupations to Census categories. To do this, I aggregated the detailed occupations in the files into four major occupational groups: laborers, operatives, craft workers, and managerial/professional. ${ }^{5}$ A hierarchy among these major occupational classifications emerges with laborers at the bottom and managerial/professional work at the top. A detailed explanation of how these jobs and occupations were coded into the major occupational groups is in Appendix A.

As shown in Table 1, the employment records also provide further information about the individual that were recorded at the time of hire. This includes race (black-white), age, marital status, and the number of dependents. Other variables were coded using information from the employment files and matching those to census data (e.g., the Duncan socioeconomic index) as noted in Appendix A. ${ }^{6}$

The analyses are described in three parts. First, I describe the workforce in each of the companies. Up to this point, Southern and Eastern European immigrants have been discussed as one category, which ignores significant inter-ethnic differences. I therefore provide detailed

\footnotetext{
${ }^{5}$ There are clerical and sales occupations in the manufacturing plants. However, there are few to no transitions between clerical/sales occupations and the other production occupations in all three companies.

${ }^{6}$ Educational attainment is also included in the samples; however, it was only recorded in these files during distinct periods within the samples. While A.M. Byers has the most complete records of educational attainment, Pullman started recording education only after 1937 and nearly sixty percent of employment records are missing education in the Ford sample. Moreover, few of the foreign-born workers in the files have recorded educational attainment. This seemingly important variable, therefore, is omitted in the analyses described below.
} 
descriptions on the composition of the workforce in these factories, paying particular attention to changes in the ethnic composition and socioeconomic changes over time. These descriptions not only show the heterogeneity among Southern and Eastern European immigrants, they also highlight labor market trajectories of different ethnic groups that would be lost in quantitative analyses.

Second, because occupational mobility within firms will depend on the occupation that an individual begins, I develop a model predicting the odds of being in different broad occupational classifications upon first occupation. Because few immigrant employment spells are in the managerial/professional category in every company, I run a multinomial logistic regression predicting workers first broad occupational category in the firm for three categories (being a laborer, operative, or craft/managerial/professional worker) with being a laborer in first occupation as the baseline. I use the control variables listed in Appendix A and predict first occupation for a pooled sample and for an immigrant-only sample. In the pooled sample, the reference category for the ethnic/immigrant categories is native-born white workers. These analyses allow us to determine whether immigrants entered the firm through different portals than native white workers. In the immigrant-only samples, I use ethnic groups that originate from Western Europe as the reference group. In the immigrant-only analyses, I also add variables based on country of citizenship and years in the United States in Byers and Pullman. Unfortunately, Ford did not keep records on these characteristics making analyses of these variables impossible.

Third, I develop a model for understanding occupational mobility within firms. ${ }^{7}$ I use a competing-risk Cox proportional-hazards model to analyze upward moves, downward moves,

\footnotetext{
${ }^{7}$ There are practical reasons for not analyzing wage mobility due to missing wage data in Byers and Pullman. Byers did not keep accurate wage data after 1934 (although they still noted occupational changes) and data only exist for
} 
and exits. Employment spells must be chronologically correct and with complete date information to be included in the Cox model. Those without correct start and end dates are likely due to transcription errors. These occupational moves are defined by ranking each occupation with laborers at the bottom and managerial/professional at the top as shown in Table 2. While the types of moves made possible by this ranking system are not equal (e.g., moving from a laborer to an operative is of less significance than moving from a laborer to a managerial position), all moves are treated equally. ${ }^{8}$ Treating all movements the same is done for practical reasons in that movement from a laborer position to a craft work (or higher) position is extremely rare making analyses unreliable. In Ford, occupational moves are clustered within individuals (i.e., a few migrants make most of the moves witnessed for their group). The proportionalhazards models are therefore not run for the Ford sample since few individuals are doing the movement.

\section{[INSERT TABLE 2 HERE]}

As mentioned earlier, leaving a firm also helps determine mobility within the firm. I therefore distinguish between voluntary departures (quits) and other forms of exiting (e.g., fired, lay-offs, going to war, dying, retiring). Quitting may occur for career or personal reasons. If groups are more likely to quit for career reasons, they may not have used internal labor markets

\footnotetext{
those who earned an hourly wage. Since many of the managers and professionals were on salary, we don't know the wages of this theoretically important category. Pullman paid workers by a combination of hourly and piece rate (with piece rates being more important in the departments that made the railroad cars). Since piece rates varied with every order that the company received, we don't know how much these workers actually made. Thus analyses for Byers and Pullman would be for select occupational groups and miss some of the theoretically important occupations.

${ }^{8}$ As a robustness check, the type of moves are separated (e.g., small moves count as a one rank change and big moves count as a two or more rank change in occupation). The results, available upon request, are similar to the analyses that combine the types of movements.
} 
as a mechanism for upward advancement. For many of the quits that occur in the data files, reasons for quitting are given. The majority of quits appear to be because of better employment opportunities outside of the firm (e.g., "quit - better job"; or "quit - found another job at Chrysler"), however, other reasons are also given like "quit - returning to old country," because of unstable or hard work, or "quit - wanted for murder." 9 Since it is impossible to know the reason for all quits in the firms, however, I analyze the hazard of quitting and make a strong assumption that most are for career reasons.

A competing risk Cox proportional hazard model is used where on any given day an individual is at risk of making an upward occupational move, a downward occupational move, quitting, or exiting the firm involuntarily. Spells are measured in duration time that occurs at different calendar times, although there is no censoring on duration. An individual becomes at risk of making an upward move, downward move, or exit when they enter the firm and the clock resets once any of the events occur. However, there is a ceiling effect when analyzing upward movement within firms (i.e. managers cannot make an upward move) and a floor effect on downward movement (i.e. laborers cannot make a downward move). Thus, once an individual becomes a manager/professional, he falls out of the risk set analyzing upward moves. However, if at a later (or earlier) time he takes an occupation other than a managerial/professional position, he becomes at risk of making an upward move again. The reverse is done when analyzing downward moves: employment spells of individuals in a laborer position are omitted from the risk set. To handle the different risk sets, I analyzed separate Cox regressions for each

\footnotetext{
${ }^{9}$ In Byers, there were 64 quits where the reason given was because of an "A.F. of L. Strike" or "man was on a mission to uplift working class - thought he was mentally ill." This suggests that the companies did not track 'quits' versus 'dismissals' very well. This may introduce measurement error in the analysis that looks at quits as opposed to other forms of leaving. However, because not all quits in the firms have information as to why the individual left, it is impossible to separate the dismissals that were coded as quits in the files. Of the workers for which exit reasons are given, I code strikers as an involuntary exit rather than a voluntary exit since it seems more likely that management forced these workers to leave the firm.
} 
destination (upward moves, downward moves, and departures) (Prentice et al. 1978). Since it is unreasonable to assume that each employment spell within each worker is independent, I adjust the standard errors of the estimated parameters to account for possible correlation. I also use the Efron method for handling ties and estimate separate models for each company.

\section{Immigrant Workers in Byers, Pullman, and Ford}

During the years of mass immigration, Byers, Pullman, and Ford drew a large foreignborn population to their factories. In the Byers files, 37 percent of workers were born in another country, nearly 30 percent of workers were foreign-born in Pullman, and 20 percent were foreign-born in Ford. The vast majority of these workers came from Southern and Eastern Europe, but individuals from Western Europe, Latin America, and the West Indies were also in the mix. The ethnic composition of these factories was also diverse. The data files report 84 different ethnicities in Byers, 94 ethnicities in Pullman, and 92 ethnicities in Ford. ${ }^{10}$ By far, Italians, Poles, and Slavs were the largest ethnic groups in the companies, but Western Europeans and Canadians also show up in large numbers in Ford. Within each group, however, there is significant heterogeneity in country of origin. For instance, Polish immigrants in Byers were born in Austria, Denmark, Germany, Poland, Prussia, and Russia. By contrast, Polish immigrants in Pullman were born in Austria, England, Hungary, Poland, and Russia. Ethnicities that originate from the Balkans had the greatest diversity in country of birth, while ethnicities that originate from Western Europe come from a singular country (e.g., English from England).

The majority of immigrants came to the US at the same time. Figure 1 plots the year of arrival to the US by descent for the Byers and Pullman files. As shown, the majority of workers

\footnotetext{
${ }^{10}$ These ethnicities include both the foreign-born and native-born. Not all ethnicities are mutually exclusive since some have been misspelled in the original employment cards and are thus coded as separate ethnicities. I correct for the misspelling in the following analyses.
} 
in each company came to the United States between 1900 and 1913. Each company reports a steep decline in entry during World War I, with a slight rebound in the early twenties. However, the migration flows virtually stopped after the 1924 Immigration Act which limited the annual number of immigrants that would be allowed to come to the United States. These entry patterns within the firms are consistent with the entry patterns for all immigrants at the national-level (Perlmann 2005).

\section{[INSERT FIGURE 1 HERE]}

On average, immigrants took 20 years after arrival in the United States to find a job in Byers and 9 years in Pullman. ${ }^{11}$ The companies, therefore, were not hiring recent arrivals. This means that most immigrants had some English-language capability. The companies recorded whether immigrant workers could speak, write, and/or read in English. In Pullman just 11 people could not speak in English, 29 could not write in English, and 26 could not read in English. Ford recorded whether an employee could speak English and only 7 individuals could not. The most variation occurs in Byers where 143 employees could not speak English, 769 could not read in English, and 803 could not write in English. ${ }^{12}$ Most workers appear to have attained the firm's minimum standards for English attainment (especially in Pullman and Ford).

After getting a job within the firm, we can begin to track socioeconomic status. As shown in Table 1, each individual had multiple jobs (e.g., the Byers and Ford workers have 6

\footnotetext{
${ }^{11}$ Because Ford does not have information on when an immigrant entered the United States, we cannot measure how long it took to find employment in its factories.

${ }^{12}$ Unfortunately, the English variables are missing from Byers in the ICPSR files making inclusion of this variable in the analyses below impossible. This information was taken from the code book. An independent check by Warren Whatley and Thomas Maloney in 2012 has confirmed that these variables are missing from ICPSR and they were unable to find an archived version of the dataset.
} 
jobs and the Pullman worker has 5). Figure 2 shows the average socioeconomic status of selected ethnic groups and native-born whites and blacks by their job number. First occupation refers to the first occupation that individuals held upon being hired. Each subsequent occupation refers to the next position that the worker had after any change in employment (e.g., wage change, department change, occupation change, etc.). A worker contributes one observation to each occupation number, although the later occupation numbers are weighted toward workers who stay in the firms longer. ${ }^{13}$

\section{[INSERT FIGURE 2 HERE]}

With the exception of German/Austrian immigrants in Byers, all immigrant groups and US-born black workers had a lower average SEI in the first occupation held in the factory than US-born whites. While these differences may or may not be significant, the average age at the time of the first job for US-born whites was 26 years old in Byers, 29 years old in Pullman and 28 years old in Ford. The average age for foreign-born workers was 34 in Byers, 31 in Pullman, and 30 in Ford. Thus, immigrants started working at lower positions than US-born whites despite being much older when initially hired. Immigrants time horizon in the firm was therefore shorter than the native-born since workers were "old at forty" in most of these occupations.

Most notable in Figure 2, however, is the low SEI scores of Italian immigrants. Here, we may be seeing the impact of weaker, less dense social networks. Italians were much less likely to settle in the industrial heartland than were Poles and other Slavs (Perlmann 2005; Waldinger

\footnotetext{
${ }^{13}$ Jobs in Figure 2 may be of any length. While this assumes that the native-born and immigrants experienced changes in jobs at a constant rate, these rates do vary in Byers and Ford. In Byers, immigrant workers changed jobs 1 to 2 months quicker than the native-born. By contrast, immigrants changed jobs 1 to 2 months slower in Ford. The median number of days in each job in Pullman, however, is similar for immigrants and nonimmigrants.
} 
2007). It may be that these workers were part of a circulatory labor migration (moving back and forth from Italy) or simply had few co-ethnic connections within the plants and therefore found it more difficult to gain any mobility within the internal labor market. Alternatively, it might be that in these areas Italians were more likely to be employed outside of manufacturing (e.g., construction) and therefore left manufacturing when they found better opportunities in Italian niches. These mechanisms may explain why Italians have lower SEI levels and progress than native Black workers in Pullman and Ford and the downward movement for Italians in Byers.

Yet other groups show different mobility trajectories than Italians. In Byers, German/Austrians obtained skilled and managerial positions before it began hiring other immigrant groups (Santos 1984). The upward trajectory of German/Austrians may reflect ethnic ties where German foremen lifted the mobility prospects for the group as a whole. This also explains why German/Austrians have a higher SEI than native white workers in each job where the foremen, efficiency engineers, and industrial engineers lift the average SEI for the group as a whole. The positive impact of these occupations on the average SEI is greater for German/Austrians than for native whites because there are relatively fewer German/Austrians in the sample.

Similar to Figure 2, wages also present the same trend. While we do not have complete wage data for Byers and Pullman, Ford kept wage information for their workers. ${ }^{14}$ Similar to Figure 2, Italians held lower nominal wages than all groups in every job (although all nominal wages increase as jobs change). For instance, in the first job, Italians earn an average of 68 cents per hour compared to a US-born white worker's 76 cents per hour. The average wage for

\footnotetext{
${ }^{14}$ Byers did not keep accurate wage data after 1934 (although they still noted occupational changes) and data only exist for those who earned an hourly wage. Pullman paid workers by a combination of hourly and piece rate (with piece rates being more important in the department that made the railroad cars). Thus, we don't know the average earnings of groups in these firms.
} 
Italians in the fifth and higher job was 85 cents per hour compared to 98 cents per hour for USborn white workers. The major difference between wages and status are for black workers who hold similar wages as US-born white workers despite the low status as shown in Figure 2. The high wages, but low status of black workers corroborates Foote, Whatley, and Wright's (2003) study that shows that there was no racial (black/white) wage variation in Ford, but black workers were given the undesirable "hot" foundry jobs characterized by low status and hazardous working conditions.

Yet the broader picture of Figure 2 shows upward mobility in Byers and Ford and lateral mobility in Pullman. However, these micro-movements in Byers and Ford are not great. For instance, Poles move up four SEI points from the first job to the fifth job in Byers and three SEI points in Ford. A one point move in SEI is equivalent to a laborer becoming a janitor (this would be an SEI 8 to a SEI 9). The small movement seen in Figure 2 keeps the average worker in the same broad occupational classification.

To show that immigrant populations rarely obtained higher occupations, Table 3 presents the number of occupational classifications by employment spell for each descent. With the exception of German/Austrians in Byers, who show 12 percent of their employment spells in managerial/professional occupations thus reflecting the high SEI from Figure 2, few of the other ethnic groups have employment spells in this category. Moreover, few of employment spells for immigrants concentrate in craft work positions thus providing evidence that internal labor market structures prevented ethnic groups from moving into higher occupational categories.

[INSERT TABLE 3 HERE] 


\section{Occupational Mobility in Byers, Pullman, and Ford}

\section{Job Entry}

As just shown, Southern and Eastern European immigrants were hired at an older age, but started at a lower occupational prestige than US-born whites within the factories. As occupations changed over time, Southern and Eastern European immigrants failed to achieve parity with native white workers and rarely held occupations at the managerial/professional level. Craft work was also relatively uncommon, leaving Southern and Eastern European immigrants in laborer and operative positions. These results suggest that immigrant workers remained in the same broad occupational category that they were initially hired - positions at the bottom. Table 4 presents a multinomial logistic regression predicting worker's first occupation at initial hire with a laborer occupation as the baseline. Analyses on both a pooled-sample and immigrant-only sample are provided with odds ratios presented for ease of interpretation.

The pooled samples of each company show many significant differences between immigrant groups and native white workers. For instance, in all three companies, Italians have significantly lower odds of being an operative or craft/managerial/professional worker in their first occupation (as opposed to being a laborer) than their native white counterparts. More striking, all Slavic groups in all three companies hold lower odds of being a craft/managerial/professional worker in their first occupation and in some cases have lower odds of starting in operative positions vis-à-vis native whites. By contrast, groups who tend to originate from more advanced countries (e.g., English in Ford, Swedish in Pullman) show no statistically discernible difference than native white workers in their first occupation. In fact, German/Austrians hold higher odds of beginning their career in the firm as an operative (as 
opposed to a laborer) than native whites in A.M. Byers. ${ }^{15}$ This does not reflect disparities in time of arrival, such that English, Swedish, or German/Austrian workers in these firms had arrived earlier than the SCEE coworkers and therefore benefited from more exposure to US customs and values, which in turn would allow them to start in higher positions. As shown in Figure 1, almost all of the immigrants arrived in the US at the same time. Those who arrived before 1900 (i.e. those with more time to assimilate) were from the "other ethnicity" category who hold lower odds of starting in operative and craft work in these firms. In unreported results, there are no substantive interaction effects between the ethnic categories and control variables in the pooled samples. Nevertheless, the pooled samples of Table 4 suggest that immigrants and native white workers entered these firms through very different hiring portals.

\section{[INSERT TABLE 4 HERE]}

The immigrant-only samples provide differences between ethnic immigrant groups in initial hire. In Byers and Pullman, immigrant specific variables (American citizenship and years in the US) are added. As shown in Table 4, Italians continue to be disadvantaged in first occupation than more privileged ethnic groups in all companies. All Slavic groups in A.M. Byers also have lower odds of being an operative in their first occupation than German/Austrians and are less likely to be an operative or a craft/managerial/professional worker in Pullman than Swedish immigrants. Similarly, Poles and Russians hold lower odds of having their first occupation be an operative (as opposed to being a laborer) than Canadians in Ford. Germans and English, however, show no difference than Canadians in first occupation.

\footnotetext{
${ }^{15}$ However, German/Austrians hold lower odds of being a craft/managerial/professional worker at initial hire than similarly situated native white workers.
} 
Having training in a trade upon time of hire for immigrants is significantly associated with starting in a higher occupation in Byers and Pullman, but not in Ford. ${ }^{16}$ Similarly, having a relative in the factory in Pullman, while failing to achieve a conventional significance level, is also associated with holding higher odds of being a craft/managerial/professional worker in first occupation (as opposed to being a laborer). This variable may either capture occupational inheritance (e.g., fathers passing their status to their sons) or the strength of ties (e.g., relatives providing jobs). Nevertheless, nepotism provided a favorable entry portal for immigrants in Pullman.

The next models in the Byers and Pullman analyses add whether an immigrant was an American citizen. Here, citizenship increases the odds that an immigrant started in an operative position (as opposed to a laborer position) at initial hire than noncitizens in both companies. American citizenship also increased the odds of being a craft/managerial/professional worker in first occupation than noncitizens in Pullman (although this odds ratio fails to achieve a conventional significance level). These results are consistent with the idea that certain occupations were held for US citizens. But while citizenship matters, this may also reflect time in the US as the naturalization process usually took several years from time of migration to complete (Bloemraad 2006). The final model adds a continuous variable for number of years in the US. In Byers, there is no statistically discernible effect for years in the US, but US citizenship significantly increases the odds that an immigrant starts in the craft/managerial/professional level. By contrast, US citizenship fails to achieve significance once number of years in the US is controlled for in Pullman. Instead, a one year increase increases the odds that an immigrant starts as an operative (as opposed to a laborer) by 5.4 percent and increases the odds that an immigrant starts as a craft/managerial/professional worker

\footnotetext{
${ }^{16}$ In unreported results, there is no significant interaction effect between the ethnic groups and previous training.
} 
(as opposed to a laborer) by 5.6 percent. However, in both Pullman and Byers, the correlation between citizenship and years in the US is high $(r>.5)$. Teasing out the effects of citizenship versus years in the US should be looked at in further research.

\section{Internal Occupational Movements and Exits}

As just shown, SCEE migrants were more likely to begin their career in laborer positions than other race/ethnic groups. Mobility for these groups, therefore, was dependent on movement in and out of the broad occupational categories defined above. Table 5 reports the number of occupational moves for each ethnicity. Here, a job spell is not defined as any change in employment (e.g., change in wage or a change in department) as it was above. Rather job spells in Table 5 ignore micro-movements within broad occupational categories and end when a major occupational move occurs (upward moves, downward moves, and exits defined in Table 2).

Table 5 shows that over eleven percent of employment spells ended with an upward occupational move for US-born white workers in A.M. Byers. Similarly, over eleven percent of job spells ended in an upward movement in Pullman and sixteen percent of job spells ended with an upward move in Ford for US-born white workers. The percent of job spells that end in an upward move for immigrants in all companies range between five and twenty-four percent. At the lower end were Poles and Slavs and the higher end Canadians and English. Because of the low power in these datasets (i.e., there few upward moves experienced by some groups), results from the following analyses should be interpreted with caution.

[TABLE 5 and 5a HERE] 
Most movements between the broad occupational categories also occur during specific time periods. Immigrant upward and downward movements occur during the mid-1910s and 1920s in all companies. The Great Depression in the 1930s nearly stopped upward moves for all workers (immigrants and native workers) and then there was a rebound during WWII. Although the Pullman data date back to the pre-immigration cutoff era, there does not appear to be a preand post-immigration cutoff effect. Immigrant workers also began to age out of the dataset since they were hired at older ages in occupations where workers were "old at 40." Thus, most of the migrants hired before 1924 made the majority of their occupational moves before the legislation that ended the open immigration era. The 1940s capture the unionization era for all companies. By this period, immigrants have begun to age out of the dataset since there was no replenishment after 1924 as shown in Figure 1. This explains why there was not a rebound in movement after the Great Depression for immigrants in all companies.

Table 6 presents the results from the competing-risk Cox-proportional hazard model described above for Byers and Pullman. ${ }^{17}$ Upward moves are reported with results from downward moves and exits available in Appendix B. Since upward moves cluster within individuals for the immigrant groups in Ford, the Cox models are not reported. Variation between immigrant groups is essentially zero in Ford and thus almost all immigrants remained in the same occupational classification that they were initially hired, which was at laborer position as shown in the previous section.

\footnotetext{
${ }^{17}$ The discrepancy between the reported number of events between Table 5 and Table 6 and Appendix B is due to missing data. In Byers, some employment spells occur before 1900. Because unemployment rates are unreliable before 1900, these individuals are left censored. The Byers analyses are run without the unemployment rate in unreported results. There are no substantive changes in the ethnic categories when unemployment is omitted. Birthdates are missing for some individuals in Pullman making age at hire unknown. Again, there are no substantive changes in the ethnic categories when hire age is omitted from the analyses.
} 
Model 1 shows that Italians and Russians hold lower hazards of making an upward move than US-born white workers in Byers. All other groups are neither more nor less likely to experience an upward move, all else equal. Since these same groups were less likely to start their career in higher positions in the firm, as shown in Table 4, fast paced movement is required for immigrants to reach parity with native white workers. The exception to this pattern is Lithuanians who show a higher hazard ratio of experiencing an upward move. Although this may provide evidence for upward advancement of this group, Lithuanians are also more likely to experience downward movement as shown in Table B1. The employment profiles of Lithuanians show that many started as a laborer then moved to an operative position for a few weeks or months and then moved to a laborer position again. Most ended their career in a laborer position. Thus the upward and downward moves made by Lithuanians are likely explained by the zigzag mobility within the firm where migrants move up, then down again in the firm.

Model 1, however, does not explicitly control for starting position. Model 2 therefore limits the sample to only those who start their first occupation in a laborer position. This analysis allows us to understand whether certain groups who start at the same position enter favorable or unfavorable job ladders at the point of entry. Again, Italians and Russians hold lower hazards of making an upward move in Byers than native white workers. Interestingly, German/Austrians, who show no difference in making an upward move in Model 1, become less likely to make an upward move once controlling for starting position (although this hazard ratio fails to achieve a conventional significance level). This suggests that German/Austrians who entered at the bottom of the job hierarchy entered unfavorable ladders similar to those of their SCEE counterparts. 
In the third model of Table 6 in the Byers analyses, there are no statistically discernible differences between immigrant groups and German/Austrians in making upward moves. In unreported results, there are also no differences between immigrant groups when controlling for starting position (similar to the tests reported in Model 2). This suggests that immigrant groups were likely hired in similar job ladders in the firm that did not allow for upward movement. Nevertheless, the mechanisms that allowed for upward mobility for immigrants are also analyzed. In Model 4, citizenship status is added to the analyses. Here, US citizens are no more likely to experience an upward movement. This is likely a result of model specification. As shown in Table 4, US citizens were more likely to start their career in higher positions in the firm. Since movement in the firm is inversely related to one's occupational level in Model 4 of Table 6, the probability of moving up for those who started in higher positions is lower because of the ceiling effect mentioned above. This same issue explains the hazard ratio of previous training that reports significantly lower hazards of making an upward move. Since previous training had such a dramatic effect on starting position in the firm in Table 4, movement upwards is unlikely because they are already at the top.

The Pullman analyses show similar results to Byers in predicting upward moves. Italians and Slavs have lower hazards of making an upward move than native white workers in Model 1. Similarly, Italians also hold lower hazards of making an upward move once controlling for starting position. The Slavic category in Model 2 shows no difference, although the sign of the hazard ratio is in the direction as predicted by internal labor market hypotheses. Interestingly, having a family member in the factory at time of hire becomes statistically significant in Model 2, suggesting that familial ties raised the prospects of upward movement for those who started at the bottom, but not necessarily at the top. Italians and Slavs are also less likely to experience an 
upward movement than Swedish immigrants in Model 3 suggesting that sending country factors may inhibit upward mobility. Similar to Byers, citizenship and years in the US show no statistically discernible effect in Models 4 and 5. These effects are likely due to the same model specification issue raised above in the Byers analyses. Thus, the mediating effects of citizenship, previous training, and years in the US on occupational mobility operates through job entry rather than improving one's chances in job ladders within the internal labor market.

\section{[TABLE 6 HERE]}

Although SCEE immigrants were less likely to experience upward mobility than more advantaged groups, it is possible that SCEE migrants did not rely on these factories for upward mobility and instead found employment in the external labor market. However, as shown in Appendix B, many SCEE groups were less likely to quit their job than native white workers. This suggests that the expected value from remaining in the factory, where perceived probabilities by workers of getting a promotion in the future, is greater than if they found employment in the external labor market (or chose non-employment). Moreover, all immigrant groups have lower hazards of quitting in Pullman. This firm attachment signals a preference for internal rather than external labor market structures. Nevertheless, these results suggest that immigrants did not make upward occupational moves within heavy manufacturing firms.

\section{Conclusion/Discussion}

My analyses provide the first tests of immigrant occupational mobility within firms in the first half of the twentieth century. The three case studies suggest that internal labor market 
structures did little to move immigrants into favorable job ladders that allowed for upward mobility. Much like the broader literature on organizations and stratification, these results speak to how organizational structures pattern mobility and create inequality in employment outcomes among different groups (Castilla 2008; Fernandez and Sosa 2005; Petersen and Saporta 2004). While the current literature on organizations and stratification use contemporary data and analyze differences in race (black/white) and gender, this paper provides a point of comparison by looking specifically at the immigrant experience in a different time period. The development of internal labor market structures, which are specifically designed to encourage promotions through job ladders in manufacturing firms (Jacoby 1984), did not counter or prevent other forces that kept European-origin immigrants from achieving upward mobility. This finding is contrary to the dominant accounts of assimilation (Alba and Nee 2003; Portes and Zhou 1993).

The above analyses focused on all parts of mobility within firms: job entry, upward and downward internal moves, and departures. Southern and Eastern European immigrants were less likely than native white workers to start their career in operative and craft/managerial positions (as opposed to starting as a laborer) and they were less likely to experience upward movement once hired. In fact, the number of upward occupational moves were relatively rare for most Southern and Eastern European immigrants in Byers and Pullman as shown in Table 4 and immigrants rarely had job spells that were in the managerial/professional category as shown in Table 3. In Ford, most of the upward moves were clustered within few individuals making analyses impossible. Moreover, in all companies, immigrants were unable to find better employment prospects in the local labor market and held on to their employment within the firms until a non-voluntary departure was made. Immigrants were therefore more dependent on the companies to make upward occupational moves. These results are consistent with internal labor 
market hypotheses that predict that immigrants lacked access to favorable job ladders within firms.

While Southern and Eastern European immigrants followed occupational trajectories as predicted by internal labor market hypotheses, Western European (and North American) immigrant groups followed occupational trajectories as predicted by assimilationists (e.g., German/Austrians in Byers and Ford, Swedish in Pullman, Canadians and English in Ford). As mentioned above, the context of origin likely influences worker predispositions to the workforce where individuals and groups from industrialized countries perform better ceteris paribus those from developing (or non-developed) countries. This finding is consistent with recent research on the occupational mobility of immigrants in the first half of the twentieth century that uses census data (Abramitzky et al. 2014). Immigrants who arrive with low skill levels are unable to close their skill gap with native white workers over time.

Mobility mechanisms for immigrants that allowed for upward mobility within firms are associated with citizenship, years in the US, familial ties, and previous training in a trade. American citizenship allowed immigrants to start their careers within firms at higher positions than non-citizens in Byers. This finding corroborates other research that suggests employers favored those who have naturalized in this time period (Bloemraad 2006). Years in the US, which is positively correlated with citizenship, played an important role in Pullman. Although these variables may reflect membership and exposure to the native-born, they may also proxy English attainment. As discussed above, the companies kept track of English attainment suggesting that almost all individuals in Pullman and Ford held some level of English competency making analyses on this variable impossible. Most of the immigrants analyzed in this study were not recent arrivals and would have been exposed to the English language. 
However, these measures do not indicate what level of competency was needed to be considered fluent by the firms. Citizenship and years in the US may be better measures to capture this variable.

Additionally, immigrants also relied on ties to family workers in the firm. Having a relative in the firm is associated with starting at a higher position in Pullman. This result is consistent with the large literature on social ties and getting a job (e.g., Waldinger and Lichter 2003; Tilly 1990). Moreover, having training in a trade dramatically increased the odds that a worker was in a craft/managerial/professional position. Structural characteristics, however, seem to have decreased the likelihood that immigrants would move up in the firm. High unemployment and having an employment spell during a world war decreased one's chances for upward advancement.

Of course, mobility mechanisms in manufacturing during this period may have taken two forms: individual upward mobility via job ladders or collective upward mobility via unionization. This article analyzes the first. The expansion of industrial unions standardized workplace dynamics and shaped cultural understandings of fairness that extended beyond its own membership that immigrant populations would have benefited from (Rosenfeld 2014). Industrial unions also reduced the negative effects of internal labor market systems because unions sought greater authority over jobs (Cohen and Pfeffer 1986). The Byers, Pullman, and Ford data covers their unionization periods. The effects of unionization are not addressed in this paper, however, because of demography and history. As shown in Figure 1, most immigrants entered the US before WWI (with a median age at entry of 19 in Byers and 20 in Pullman). The three companies unionized relatively late (1937 in Byers, 1948 in Pullman, and 1941 in Ford). Because the 1924 Immigration Act virtually stopped all immigration flows, there is not enough 
replenishment of immigrant populations to make analyses on unionization possible. For the most part, immigrants have aged out of the data set by the unionization era. It was therefore the second and third generation that was likely the greatest beneficiary of these effects since they came of working age at the height of union membership. While unionization is correlated with manufacturing in this time, membership extended well beyond the factory walls. Thus, if industrial unions were the mechanism that produced upward assimilation, we cannot attribute all of its success to manufacturing.

This article focuses on an often cited, but never researched issue in assimilation research. Assimilation theories often point to manufacturing in the past and then make inferences about today's immigrants. Segmented assimilation suggests that job ladders in manufacturing allowed for upward mobility that is no longer available to today's immigrants. As a result, proponents of segmented assimilation suggest that the obstacles faced by yesterday's immigrants were of a significantly lesser sort. However, this paper clearly shows that access to favorable job ladders was segmented. Neo-assimilation theories point to the past and suggest that it is a reliable guide for today's immigrants where they argue that "...the rough uniformity of outcome is hard to overlook, and it suggests the possibility that forces promoting assimilation are well entrenched in the American social order..." (Alba and Nee 2003: 125). Continuity derives from an underlying mechanism that should be temporally invariant: the rational action of individuals choosing the "optimum range of mobility chances" rather than "strong attachment to an ethnic community and culture" (Alba and Nee 2003: 125). However, there is tension in this framework since Alba and Nee (2003) also invoke period effects to explain the assimilation of SCEE migrants, albeit in somewhat contradictory ways. On the one hand they contend that assimilation of SCEE were "based on historical contingent periods of economic expansion that allowed immigrants of 
peasant origin with few working skills of relevance...to gain a foothold through steady employment, often in manufacturing sectors..." (Alba and Nee 2003: 135; emphasis added). On the other hand, they contend that the changes generated by the New Deal, the war economy, and the post-war prosperity powered second generation mobility (104-5). In any case, since parent's social position deeply influences children's social destinations, future research should analyze how the second generation made upward moves given their parent's low status in manufacturing firms uncovered in the above analyses.

This article does not argue that there was no period effect in producing rapid assimilation. Nor does it suggest that migrants did not experience mobility in other sectors such as light manufacturing, warehousing, construction, and self-employment. Rather, it suggests that upward mobility among SCEE groups was likely not the result of job ladders in manufacturing as proponents of assimilation theories assert. While the subfield of immigration and assimilation is plagued with presentism (Waldinger 2007), the release of once confidential data (full-count censuses, naturalization records, etc.) both in the US and abroad allows researchers to understand aspects of the immigrant experience previously difficult or impossible to explore, and thus making for ever productive debates (Abramitzky et al. 2012, 2013, 2014; Biavaschi et al. 2013; Conner 2015; Shertzer 2013). 


\section{Appendix A: Detailed Variable Recodes}

Major Occupational Groups: To classify the occupation titles in the data under the four major occupational groups (laborers, operatives, craft workers, managerial/professional), I used the 1950 Classified Index of Occupations and Industries (CIOI) and the 1939 Dictionary of Occupational Titles (DOT). The CIOI is designed for use in classifying occupations from the Population Censuses and other demographic surveys conducted by the Census Bureau. The DOT was created and published by the U.S. Department of Labor as a reference manual for the use of the U.S. Employment Service to match job applicants with jobs (Cain and Treiman 1981). Both make it possible to classify detailed occupations into major occupational groups defined above with the DOT providing more detailed information about each occupation.

First, occupations that are found in the CIOI were coded in respect to their major occupational group. The CIOI provides a list of many occupations that are found under larger occupational groups. In the event that the occupation from the data set was not in the CIOI, the DOT was consulted to identify what major occupational code the occupation belongs under. Unlike the CIOI, which classifies occupations based on craft work, operatives, laborers, etc., however, the DOT classifies occupations based on skill (skilled, semiskilled, and unskilled). The DOT provides a three-digit grouping system to identify skill as well as the definition of tasks performed by the occupation. If the occupation was identified as a skilled job, I coded these as craft workers. Semiskilled occupations were coded as operatives; and unskilled jobs were coded as laborers (most often, the definition of tasks also identified these occupations as a laborer). These codes are roughly analogous to the Census's classification system (Cain and Treiman 1981).

Although helpers "may be expected to learn the occupation or trade of the worker he assists" (DOT 1939: 450), they were coded as laborers because the skill required was often minimal and these positions rarely translated into workers entering occupation for which he was helping. Assistants, learners, and apprentices, however, were coded as the same occupation as the occupation assisted since they essentially performed the same tasks and duties as the worker assisted unlike helpers whose duties were clearly subordinated. In Pullman and Ford, many occupational titles correspond with what the person installed on the train cars (the job versus the occupation e.g., 'camshaft'). I coded these as subassemblers/installers (operatives). In some cases, the occupational title given in the data files could potentially mean that workers were either in production or clerical. For instance, checkers may either be clerical workers or an inspector on the production line. To separate clerical workers versus inspectors, I checked the department for which the employment spell occurred. If the checker worked in clerical departments like "accounting," they were coded as clerks, but if the checker worked in departments like the "finish line," I coded these as inspectors (which were coded as managerial/professional workers since these jobs often included similar tasks as foremen). Other occupations similar to checkers (e.g., filers, watchmen) were given the same consideration. Because departments in the Ford files are numbers as opposed to names, these occupations were assumed to be production unless the occupational title made it possible to determine otherwise (e.g., stock checkers and stock filers were clerical).

In some cases, occupations died before the DOT and CIOI were published. For instance, A.M. Byers was the last major company that hired puddlers. In 1930, Byers developed the Byers Process and opened the Ambridge plant that effectively killed puddling as an occupation. The DOT and CIOI label this occupation as an operative, but at the time, this was craft work as noted 
in former U.S. Secretary of Labor James Davis's 1921 autobiography. Using this historical knowledge, puddlers were coded as craft workers rather than operatives. Of the 19,736 employment spells in the original dataset in A.M. Byers, I was unable to match a corresponding broad occupational classification to 275 employment spells (which includes 158 spells not identified in the original data collection). This represents 48 of the 983 production occupations in the files. In Pullman, I was unable to code 294 of the 1,892 production occupations. This comprises 1,373 of 12,986 employment spells of which 526 had no occupational information in the original data project. Similarly, in Ford, I was unable to code 42 production occupations, which comprises 848 of 15,215 employment spells.

Immigrant Status: To understand the social mobility among immigrants, it is important to separate the foreign-born from the native-born. As shown in Table 1, the companies provide information on a person's descent/ethnicity for those who were born outside the US and in a few cases individuals who were born in the US, presumably because they were second generation. The rest of the employees who were born in the US have missing ethnic labels or were identified as "American," which was common practice during this period (Fischer and Hout 2006). As noted in the text, immigrant status is obtained through a variety of variables in the Byers and Pullman data sets. First, if the worker's birth state was anywhere outside of the United States, the worker was coded as an immigrant. However, there are some employees who are missing state or country of birth, but are of European-origin descent. In order to determine whether these employees were born in another country, I used other information provided by the companies based on their country of citizenship and reported years in the US. If an individual was a citizen of a country other than the US or has been in the US for fewer years than he has been alive, I coded the employee as an immigrant. Any remaining individuals without birthplace information (49 people in Byers and 39 people in Pullman) were dropped from the analysis.

The Ford files are set up differently than Byers and Pullman. The company kept records of individuals' nationality/citizenship/race in one variable and ethnicity for many US-born workers in another. The state (or country) of birth, however, was only coded for those born in the US (and in a couple of exceptions in Canada). Rather than coding immigrant status by birthplace, citizenship, ethnicity, and years in the US, immigrants in Ford are identified through their reported nationality (which also includes information on descent). Native-born workers are those with an "American" or "American colored" (black) nationality label.

American Citizenship: Byers and Pullman recorded citizenship status. This variable is coded as 1 if the worker is an American citizen and 0 otherwise.

Years in the US: In Byers, years in the US is found by taking the first year that an immigrant was employed in the firm minus the year that he entered the United States. Pullman recorded the years in the US. This is a continuous variable in the analyses.

Hire age: Hire age is the employee's age at the time of hire. This variable is a continuous variable in the multinomial logit predicting first occupation and fixed at its value when the individual entered the firm in the Cox model predicting occupational movements. 
Married: This variable represents the employee's marital status at the time of hire. This variable is coded as 1 if the employee is married and 0 otherwise. This is fixed in the Cox model.

Employee's Relatives Work in Factory: Pullman kept records indicating whether an employee's relatives also worked at the time of hire. Sometimes the data indicate how many relatives work for the company and other times describe the type of relative and his/her department and occupation (e.g., Father/Foundry). In the Pullman analyses, this variable is coded as 1 if the employee has at least one relative in the company and 0 otherwise.

Previous Training: When the employee was hired, the trade for which the employee was trained was recorded. This variable is coded as 1 if the worker had training at the time of hire and 0 otherwise. This variable is fixed in the Cox models because we don't know whether he entered a training program after he was initially hired.

Wage Type: This variable represents the method of wage-payment for the current job in A.M. Byers. This variable is coded as 1 if the employee is paid hourly and 0 otherwise. In the files, there are many missing values. The range of available wages in Byers show that almost all of the missing values are greater than the range of available wages for those who are paid hourly. I therefore assume that the missing values are not hourly work, but rather some other form of wage type. In Pullman and Ford, virtually all workers were paid an hourly wage. This variable is therefore omitted in the Pullman and Ford analyses. Wage type is included as a time varying covariate in the Cox model in Byers, but omitted from the multinomial logit predicting first occupation.

Duncan Socioeconomic Index (SEI): Because there is a potential floor and ceiling effect on occupational mobility, where the higher the prestige of the current occupation, the more difficult it is to find a job, SEI of the current occupation is controlled for as a time varying coefficient in the Cox model. SEI scores were assigned to each occupation in the companies. First, I assigned SEI scores to all occupations in the company files that appear in the 1950 census. These include occupations such as hammermen, heaters, and foremen. Next, I used the 1950 Classified Index of Occupations and Industries to code occupational titles and SEI scores that were not in the 1950 census, but fall under broader occupational categories defined by the Census Bureau. Examples of these occupations include the fagot maker, scale wheeler, and sand wheeler shown in the Byers employment profile from Table 1, which are laborer positions. In the rare event that the occupation titles in the data files were not located in the 1950 census or the Classified Index, I consulted the 1939 Dictionary of Occupational Titles to give a best guess estimate of the type of occupation and corresponding SEI. Most often, these were laborer positions and general operative occupations, not elsewhere classified. If I was able to classify the major occupation of each detailed occupation, but could not find a corresponding SEI, I assigned the SEI for the major occupational code, not elsewhere classified (e.g., operatives, n.e.c. were given a SEI score of 18; laborers, n.e.c. were given a SEI score of 8).

Factory: This variable represents a dummy variable for the factory that the employee worked in. The Pullman files only come from one factory while Byers has two and Ford has four. In the Byers and Ford files, factory is included as a fixed effect where all workers share the same 
baseline hazard function and the effect of the factory multiplies this function up or down based on the sign of the estimated coefficients of the factory indicator variables. We cannot track movement between factories in Byers. However, in some cases, employees report working in multiple factories in Ford making this a time varying covariate in the Cox model.

Unemployment Rate: This variable represents the yearly non-farm unemployment rate in the United States to capture the effects of the business cycle. The data come from Lebergott (1964, Table A-3) and the Current Population Survey for the years after 1960. It is included as a time varying covariate.

World Wars: A dummy variable for each World War is included in the analyses that switch on in the war years and off in the non-war years. 


\section{Appendix B}

Table B1: Competing risk Cox-proportional hazard model predicting downward moves among non-laborer occupations within firms

\begin{tabular}{|c|c|c|c|c|}
\hline \multicolumn{5}{|l|}{ A.M. Byers Company } \\
\hline & \multirow{2}{*}{$\begin{array}{c}\text { Pooled Sample } \\
\text { Model (1) }\end{array}$} & \multicolumn{3}{|c|}{ Immigrant Only Sample } \\
\hline & & Model (2) & Model (3) & Model (4) \\
\hline \multicolumn{5}{|c|}{ US-born white (reference) } \\
\hline US-born black & $\begin{array}{r}2.192 \\
(6.70)^{* * *}\end{array}$ & & & \\
\hline German/Austrian & $\begin{array}{r}.622 \\
(-1.58)\end{array}$ & & & \\
\hline Italian & $\begin{array}{r}1.086 \\
(.18)\end{array}$ & $\begin{array}{l}2.051 \\
(1.27)\end{array}$ & $\begin{array}{l}2.068 \\
(1.29)\end{array}$ & $\begin{array}{l}2.307 \\
(1.32)\end{array}$ \\
\hline Lithuanian & $\begin{array}{r}2.139 \\
(3.46)^{* *}\end{array}$ & $\begin{array}{r}3.327 \\
(3.44)^{* *}\end{array}$ & $\begin{array}{r}3.192 \\
(3.27)^{* *}\end{array}$ & $\begin{array}{r}3.186 \\
(3.00)^{* *}\end{array}$ \\
\hline Polish & $\begin{array}{r}1.168 \\
(1.07)\end{array}$ & $\begin{array}{r}1.984 \\
(2.17)^{*}\end{array}$ & $\begin{array}{r}1.926 \\
(2.07)^{*}\end{array}$ & $\begin{array}{r}1.904 \\
(1.87)+\end{array}$ \\
\hline Russian & $\begin{array}{r}2.189 \\
(3.05)^{* *}\end{array}$ & $\begin{array}{r}3.577 \\
(3.47)^{* *}\end{array}$ & $\begin{array}{r}3.395 \\
(3.24)^{* *}\end{array}$ & $\begin{array}{r}3.592 \\
(2.94)^{* * *}\end{array}$ \\
\hline Ruthanian & $\begin{array}{r}.859 \\
(-.50)\end{array}$ & $\begin{array}{r}1.469 \\
(.94)\end{array}$ & $\begin{array}{r}1.404 \\
(.83)\end{array}$ & $\begin{array}{r}1.764 \\
(1.28)\end{array}$ \\
\hline Other Slav & $\begin{array}{r}1.202 \\
(.74)\end{array}$ & $\begin{array}{r}1.966 \\
(1.84)+\end{array}$ & $\begin{array}{r}1.890 \\
(1.71)+\end{array}$ & $\begin{array}{l}1.803 \\
(1.39)\end{array}$ \\
\hline Other ethnicity & $\begin{array}{r}1.009 \\
(.05)\end{array}$ & $\begin{array}{r}1.739 \\
(1.63)\end{array}$ & $\begin{array}{r}1.806 \\
(1.73)\end{array}$ & $\begin{array}{r}.905 \\
(-.18)\end{array}$ \\
\hline Immigrant variables & & & & \\
\hline American citizenship & & & $\begin{array}{r}.898 \\
(-.61)\end{array}$ & $\begin{array}{r}.814 \\
(-.96)\end{array}$ \\
\hline Years in US & & & & $\begin{array}{r}.993 \\
(-.90)\end{array}$ \\
\hline Hire age & $\begin{array}{r}.999 \\
(-.08)\end{array}$ & $\begin{array}{r}1.010 \\
(1.45)\end{array}$ & $\begin{array}{l}1.009 \\
(1.44)\end{array}$ & $\begin{array}{l}1.011 \\
(1.05)\end{array}$ \\
\hline Married & $\begin{array}{r}.762 \\
(-2.77)^{* *}\end{array}$ & $\begin{array}{r}.697 \\
(-2.28)^{*}\end{array}$ & $\begin{array}{r}.701 \\
(-2.28)^{*}\end{array}$ & $\begin{array}{r}.639 \\
(-2.32)^{*}\end{array}$ \\
\hline Hourly & $\begin{array}{r}2.218 \\
(7.12)^{* * * *}\end{array}$ & $\begin{array}{r}3.282 \\
(5.43)^{* * * *}\end{array}$ & $\begin{array}{r}3.271 \\
(5.41)^{* * * *}\end{array}$ & $\begin{array}{r}2.394 \\
(3.22)^{* *}\end{array}$ \\
\hline Previous training & $\begin{array}{r}.445 \\
(-3.42)^{* *}\end{array}$ & $\begin{array}{r}.424 \\
(-2.04)^{*}\end{array}$ & $\begin{array}{r}.729 \\
(-2.01)^{*}\end{array}$ & $\begin{array}{r}.686 \\
(-.62)\end{array}$ \\
\hline SEI & $\begin{array}{r}.982 \\
(-.77)\end{array}$ & $\begin{array}{r}.958 \\
(-1.21)\end{array}$ & $\begin{array}{r}.958 \\
(-1.20)\end{array}$ & $\begin{array}{r}.985 \\
(-.36)\end{array}$ \\
\hline SEI-squared & $\begin{array}{r}.999 \\
(-.04)\end{array}$ & $\begin{array}{l}1.001 \\
(1.18)\end{array}$ & $\begin{array}{l}1.001 \\
(1.19)\end{array}$ & $\begin{array}{r}1.000 \\
(.56)\end{array}$ \\
\hline Ambridge (factory) & $\begin{array}{r}.713 \\
(-2.58)^{*}\end{array}$ & $\begin{array}{r}.658 \\
(-1.39)\end{array}$ & $\begin{array}{r}.671 \\
(-1.32)\end{array}$ & $\begin{array}{r}.476 \\
(-1.87)+\end{array}$ \\
\hline Unemployment & $\begin{array}{r}.977 \\
(-4.01)^{* * *}\end{array}$ & $\begin{array}{r}.971 \\
(-3.03)^{* *}\end{array}$ & $\begin{array}{r}.971 \\
(-3.01)^{* *}\end{array}$ & $\begin{array}{r}.979 \\
(-2.02)^{*}\end{array}$ \\
\hline WWI & $\begin{array}{r}.744 \\
(-2.13)^{*}\end{array}$ & $\begin{array}{r}.701 \\
(-2.02)^{*}\end{array}$ & $\begin{array}{r}.700 \\
(-2.03)^{*}\end{array}$ & $\begin{array}{r}.421 \\
(-2.65)^{* *}\end{array}$ \\
\hline WWII & $\begin{array}{r}.319 \\
(-4.67)^{* * *}\end{array}$ & $\begin{array}{r}.337 \\
(-2.40)^{*}\end{array}$ & $\begin{array}{r}.342 \\
(-2.36)^{*}\end{array}$ & $\begin{array}{r}.234 \\
(-2.44)^{*}\end{array}$ \\
\hline Log pseudolikelihood & $-4,030$ & $-1,723$ & $-1,693$ & -1151 \\
\hline AIC & 9,709 & 3,481 & 3,482 & 2,339 \\
\hline Number of failures & 683 & 276 & 276 & 201 \\
\hline Number of individuals & 2,409 & 947 & 947 & 456 \\
\hline
\end{tabular}


Table B1 continued: Pullman-Standard Manufacturing

\begin{tabular}{|c|c|c|c|c|}
\hline & \multirow{2}{*}{$\begin{array}{c}\text { Pooled Sample } \\
\text { Model (1) }\end{array}$} & \multicolumn{3}{|c|}{ Immigrant-only sample } \\
\hline & & Model (2) & Model (3) & Model (4) \\
\hline \multicolumn{5}{|c|}{ US-born white (reference) } \\
\hline \multirow[t]{2}{*}{ US-born black } & 1.450 & & & \\
\hline & $(1.80)+$ & & & \\
\hline \multirow{2}{*}{ Swedish } & 1.542 & & & \\
\hline & $(1.15)$ & & & \\
\hline \multirow{2}{*}{ Italian } & 1.622 & 1.379 & 1.439 & 2.512 \\
\hline & $(.85)$ & $(.44)$ & $(.50)$ & $(.94)$ \\
\hline \multirow[t]{2}{*}{ Slavic } & 477 & .385 & .348 & .593 \\
\hline & $(-1.58)$ & $(-1.61)$ & $(1.69)+$ & $(-.78)$ \\
\hline \multirow[t]{2}{*}{ Other ethnicity } & 1.467 & 1.015 & .997 & 1.495 \\
\hline & $(1.74)+$ & $(.04)$ & $(-.01)$ & (1.16) \\
\hline \multicolumn{5}{|l|}{ Immigrant variables } \\
\hline \multirow[t]{2}{*}{ US citizen } & & & 1.329 & 1.207 \\
\hline & & & $(1.03)$ & $(.69)$ \\
\hline \multirow{2}{*}{\multicolumn{2}{|c|}{ Years in the United }} & & & .988 \\
\hline & & & & $(-.70)$ \\
\hline \multirow[t]{2}{*}{ Hire age } & 1.002 & .997 & .999 & .986 \\
\hline & $(.16)$ & $(-.15)$ & $(-.05)$ & $(-.87)$ \\
\hline \multirow[t]{2}{*}{ Married } & 1.048 & 1.075 & .958 & .971 \\
\hline & $(.25)$ & $(.25)$ & $(-.14)$ & $(-.09)$ \\
\hline \multirow[t]{2}{*}{ Previous training } & 1.073 & 1.579 & 1.605 & 1.783 \\
\hline & $(.41)$ & $(1.34)$ & $(1.34)$ & $(1.32)$ \\
\hline \multirow{2}{*}{ Relative in the factory } & 1.249 & 1.522 & 1.461 & 1.898 \\
\hline & $(1.12)$ & $(1.45)$ & $(1.32)$ & $(2.25)^{*}$ \\
\hline \multirow[t]{2}{*}{ SEI } & 1.083 & 1.199 & 1.195 & 1.294 \\
\hline & $(2.80)^{* *}$ & $(2.79)^{* *}$ & $(2.67) * *$ & $(3.45)^{* *}$ \\
\hline \multirow[t]{2}{*}{ SEI square } & .999 & .998 & .998 & .997 \\
\hline & $(-2.40)^{*}$ & $(-2.27)^{*}$ & $(-2.67)^{*}$ & $(-2.79) * *$ \\
\hline \multirow[t]{2}{*}{ Unemployment rate } & .996 & 1.008 & 1.006 & .998 \\
\hline & $(-.35)$ & $(.49)$ & $(.37)$ & $(-.12)$ \\
\hline \multirow[t]{2}{*}{ WWI } & .805 & .749 & .790 & .767 \\
\hline & $(-.66)$ & $(-.76)$ & $(-.62)$ & $(-.65)$ \\
\hline \multirow[t]{2}{*}{ WWII } & 2.393 & 2.622 & 2.486 & 4.761 \\
\hline & $(4.43)^{* * *}$ & $(2.06)^{*}$ & $(1.91)+$ & $(3.75) * * *$ \\
\hline Log pseudolikelihood & -1288 & -388 & -1145 & -284 \\
\hline AIC & 2602 & 800 & 787 & 596 \\
\hline Number of failures & 188 & 69 & 69 & 55 \\
\hline Number of individuals & 1,502 & 478 & 478 & 408 \\
\hline
\end{tabular}

$+.05<\mathrm{p}<.1, * \mathrm{p}<.05, * * \mathrm{p}<.01, * * * \mathrm{p}<.001$ (two-tailed)

Note: Hazard ratios are reported with $z$-statistics in the parentheses. 
Table B2: Competing risk Cox-proportional hazard model predicting voluntary exits (quits) from firms

\begin{tabular}{|c|c|c|c|c|}
\hline \multicolumn{5}{|l|}{ A.M. Byers Company } \\
\hline & \multirow{2}{*}{$\begin{array}{c}\text { Pooled Sample } \\
\text { Model (1) }\end{array}$} & \multicolumn{3}{|c|}{ Immigrant Only Sample } \\
\hline & & Model (2) & Model (3) & Model (4) \\
\hline \multicolumn{5}{|c|}{ US-born white (reference) } \\
\hline US-born black & $\begin{array}{r}.979 \\
(-.36)\end{array}$ & & & \\
\hline German/Austrian & $\begin{array}{r}.827 \\
(-1.35)\end{array}$ & & & \\
\hline \multirow[t]{2}{*}{ Italian } & .938 & 1.427 & 1.422 & 1.579 \\
\hline & $(-.61)$ & $(2.00)^{*}$ & $(1.98)^{*}$ & $(2.00)^{*}$ \\
\hline \multirow[t]{2}{*}{ Lithuanian } & .850 & 1.002 & .975 & .705 \\
\hline & $(-1.04)$ & $(.01)$ & $(-.12)$ & $(-1.39)$ \\
\hline \multirow[t]{2}{*}{ Polish } & .668 & .779 & .763 & .809 \\
\hline & $(-5.95) * * *$ & $(-1.69)+$ & $(-1.82)+$ & $(-1.09)$ \\
\hline \multirow[t]{2}{*}{ Russian } & .682 & .822 & .797 & .964 \\
\hline & $(-2.89) * *$ & $(-1.05)$ & $(-1.19)$ & $(-.16)$ \\
\hline \multirow[t]{2}{*}{ Ruthanian } & .783 & .870 & .841 & .951 \\
\hline & $(-2.34)^{*}$ & $(-.84)$ & $(-1.03)$ & $(-.23)$ \\
\hline \multirow[t]{2}{*}{ Other Slav } & .574 & .744 & .727 & .791 \\
\hline & $(5.52) * * *$ & $(-1.75)+$ & $(-1.86)+$ & $(-1.07)$ \\
\hline \multirow[t]{2}{*}{ Other ethnicity } & 1.201 & 1.418 & 1.447 & 1.537 \\
\hline & $(2.76)^{* *}$ & $(2.37)^{*}$ & $(2.47)^{*}$ & $(1.95)+$ \\
\hline \multicolumn{5}{|l|}{ Immigrant variables } \\
\hline American citizenship & & & $\begin{array}{r}.938 \\
(-.81)\end{array}$ & $\begin{array}{r}.789 \\
(-2.20)^{*}\end{array}$ \\
\hline Years in US & & & & $\begin{array}{r}.981 \\
(-4.04)^{* * *}\end{array}$ \\
\hline \multirow[t]{2}{*}{ Hire age } & .997 & .994 & .994 & .997 \\
\hline & $(-1.76)+$ & $(-2.44)^{*}$ & $(-2.40)^{*}$ & $(-.62)$ \\
\hline \multirow[t]{2}{*}{ Married } & .961 & .999 & .999 & 1.076 \\
\hline & $(-.98)$ & $(-.01)$ & $(-.00)$ & $(.84)$ \\
\hline \multirow{2}{*}{ Hourly } & 1.174 & 1.452 & 1.449 & 1.568 \\
\hline & $(3.80)^{* * *}$ & $(4.43)^{* * *}$ & $(4.41)^{* * *}$ & $(3.66)^{* * *}$ \\
\hline \multirow[t]{2}{*}{ Previous training } & 1.276 & 1.321 & 1.325 & 1.559 \\
\hline & $(3.68)^{* * *}$ & $(2.40)^{*}$ & $(-2.42)^{*}$ & $(2.61)^{* *}$ \\
\hline \multirow[t]{2}{*}{ SEI } & .963 & .968 & .968 & .967 \\
\hline & $(-8.57)^{* * *}$ & $(-3.41)^{* *}$ & $(-3.43) * *$ & $(-2.88) * *$ \\
\hline \multirow[t]{2}{*}{ SEI-squared } & 1.0004 & 1.0002 & 1.0002 & 1.0003 \\
\hline & $(6.04)^{* * *}$ & (1.17) & $(1.19)$ & $(1.28)$ \\
\hline \multirow{2}{*}{ Ambridge (factory) } & .656 & .443 & .448 & .429 \\
\hline & $(-7.94) * * *$ & $(-6.45)^{* * * *}$ & $(-6.33) * * *$ & $(-5.86) * * *$ \\
\hline Unemployment & .975 & 962 & .962 & .969 \\
\hline & $(-10.46) * * *$ & $(-7.20) * * *$ & $(-7.20) * * *$ & $(-5.10) * * *$ \\
\hline WWI & 1.094 & 1.137 & 1.137 & .883 \\
\hline & $(-1.87)+$ & $(2.08)^{*}$ & $(-2.08)^{*}$ & $(-.97)$ \\
\hline WWII & .958 & .753 & .759 & .674 \\
\hline & $(-.85)$ & $(-2.04)^{*}$ & $(-1.97) *$ & $(-2.42)^{*}$ \\
\hline Log pseudolikelihood & $-34,138$ & $-10,767$ & $-11,767$ & $-4,886$ \\
\hline $\mathrm{AIC}$ & 68,314 & 21,568 & 21,569 & 2423 \\
\hline Number of failures & 4,050 & 1,451 & 1,451 & 714 \\
\hline Number of individuals & 6,221 & 2,337 & 2,337 & 1,009 \\
\hline
\end{tabular}


Table B2 continued: Pullman-Standard Manufacturing

\begin{tabular}{|c|c|c|c|c|}
\hline & \multirow{2}{*}{$\begin{array}{c}\text { Pooled Sample } \\
\text { Model (1) }\end{array}$} & \multicolumn{3}{|c|}{ Immigrant-only sample } \\
\hline & & Model (2) & Model (3) & Model (4) \\
\hline \multicolumn{5}{|c|}{ US-born white (reference) } \\
\hline \multirow{2}{*}{ US-born black } & .850 & & & \\
\hline & $(-1.78)+$ & & & \\
\hline \multirow[t]{2}{*}{ Swedish } & .686 & & & \\
\hline & $(-1.91)+$ & & & \\
\hline \multirow[t]{2}{*}{ Italian } & .599 & .803 & .766 & .933 \\
\hline & $(-2.84) * *$ & $(-.84)$ & $(-1.02)$ & $(-.25)$ \\
\hline \multirow[t]{2}{*}{ Slavic } & .673 & .963 & .949 & .832 \\
\hline & $(-2.79) * *$ & $(-.17)$ & $(-.23)$ & $(-.78)$ \\
\hline \multirow{2}{*}{ Other ethnicity } & .682 & .952 & .966 & .960 \\
\hline & $(-3.76)^{* * * *}$ & $(-.24)$ & $(-.17)$ & $(-.20)$ \\
\hline \multicolumn{5}{|l|}{ Immigrant variables } \\
\hline \multirow[t]{2}{*}{ US citizen } & & & .726 & .716 \\
\hline & & & $(-1.96)^{*}$ & $(-1.94)+$ \\
\hline \multicolumn{2}{|l|}{ Years in the United } & & & 1.022 \\
\hline \multicolumn{2}{|l|}{ States } & & & $(2.62)^{* *}$ \\
\hline \multirow[t]{2}{*}{ Hire age } & 995 & .993 & .994 & .989 \\
\hline & $(-1.20)$ & $(-1.05)$ & $(-.95)$ & $(-1.42)$ \\
\hline \multirow[t]{2}{*}{ Married } & .839 & .809 & .859 & .795 \\
\hline & $(-2.42)^{*}$ & $(-1.66)+$ & $(-1.18)$ & $(1.67)+$ \\
\hline \multirow[t]{2}{*}{ Previous training } & .811 & .638 & .656 & .515 \\
\hline & $(-2.05)^{*}$ & $(-1.82)+$ & $(-1.78)+$ & $(-2.56)^{*}$ \\
\hline \multirow[t]{2}{*}{ Relative in the factory } & .605 & .463 & .515 & .488 \\
\hline & $(-4.51)^{* * *}$ & $(-3.64) * * *$ & $(-3.10)^{* *}$ & $(-3.28) * *$ \\
\hline \multirow{2}{*}{ SEI } & .976 & .956 & .959 & .954 \\
\hline & $(-3.19) * *$ & $(-3.48) * *$ & $(-3.20) * *$ & $(-3.51) * * *$ \\
\hline \multirow[t]{2}{*}{ SEI square } & 1.0002 & 1.001 & 1.001 & 1.001 \\
\hline & $(2.01)^{*}$ & $(2.82)^{* *}$ & $(2.72)^{* *}$ & $(2.92)^{* *}$ \\
\hline \multirow[t]{2}{*}{ Unemployment rate } & .956 & .959 & .960 & .955 \\
\hline & $(-8.69) * * *$ & $(-5.35) * * *$ & $(-5.24) * * *$ & $(-5.26) * * *$ \\
\hline \multirow[t]{2}{*}{ WWI } & 1.546 & .963 & .959 & 1.009 \\
\hline & $(5.59) * * *$ & $(-.27)$ & $(-.30)$ & $(.06)$ \\
\hline \multirow[t]{2}{*}{ WWII } & .841 & 1.138 & 1.264 & 1.018 \\
\hline & $(-1.95)+$ & $(.59)$ & $(1.06)$ & $(.08)$ \\
\hline Log pseudolikelihood & -10496 & -2926 & -2923 & $-2,411$ \\
\hline AIC & 21020 & 5876 & 5872 & 4850 \\
\hline Number of failures & 1395 & 452 & 452 & 385 \\
\hline Number of individuals & 2383 & 773 & 773 & 639 \\
\hline
\end{tabular}

$+.05<\mathrm{p}<.1, * \mathrm{p}<.05, * * \mathrm{p}<.01, * * * \mathrm{p}<.001$ (two-tailed)

Note: Hazard ratios are reported with $z$-statistics in the parentheses. 
Table B3: Competing risk Cox-proportional hazard model predicting other exits from firms

\begin{tabular}{|c|c|c|c|c|}
\hline \multicolumn{5}{|c|}{ A.M. Byers Company } \\
\hline & Model (1) & Model (2) & Model (3) & Model (4) \\
\hline \multicolumn{5}{|c|}{ US-born white (reference) } \\
\hline US-born black & $\begin{array}{r}1.180 \\
(3.34)^{* *}\end{array}$ & & & \\
\hline German/Austrian & $\begin{array}{r}.848 \\
(-1.56)\end{array}$ & & & \\
\hline Italian & $\begin{array}{r}.973 \\
(-.30)\end{array}$ & $\begin{array}{r}1.309 \\
(1.96)^{*}\end{array}$ & $\begin{array}{r}1.324 \\
(2.03)^{*}\end{array}$ & $\begin{array}{r}1.220 \\
(1.27)\end{array}$ \\
\hline Lithuanian & $\begin{array}{l}1.147 \\
(1.11)\end{array}$ & $\begin{array}{r}1.298 \\
(1.73)+\end{array}$ & $\begin{array}{l}1.362 \\
(2.03)^{*}\end{array}$ & $\begin{array}{r}1.311 \\
(1.59)\end{array}$ \\
\hline Polish & $\begin{array}{r}.876 \\
(-2.28)^{*}\end{array}$ & $\begin{array}{r}1.028 \\
(.25)\end{array}$ & $\begin{array}{r}1.068 \\
(.58)\end{array}$ & $\begin{array}{r}1.072 \\
(.54)\end{array}$ \\
\hline Russian & $\begin{array}{c}1.117 \\
(1.05)\end{array}$ & $\begin{array}{r}1.312 \\
(1.94)+\end{array}$ & $\begin{array}{r}1.383 \\
(2.28)^{*}\end{array}$ & $\begin{array}{r}1.529 \\
(2.57)^{*}\end{array}$ \\
\hline Ruthanian & $\begin{array}{r}.788 \\
(-2.22)^{*}\end{array}$ & $\begin{array}{r}.909 \\
(-.67)\end{array}$ & $\begin{array}{r}.967 \\
(-.23)\end{array}$ & $\begin{array}{r}.952 \\
(-.27)\end{array}$ \\
\hline Other Slav & $\begin{array}{r}1.050 \\
(.64)\end{array}$ & $\begin{array}{r}1.326 \\
(2.28)^{*}\end{array}$ & $\begin{array}{r}1.381 \\
(2.59)^{*}\end{array}$ & $\begin{array}{r}1.486 \\
(2.75)^{* *}\end{array}$ \\
\hline Other ethnicity & $\begin{array}{r}1.734 \\
(10.24)^{* * *}\end{array}$ & $\begin{array}{r}2.055 \\
(6.66)^{* * * *}\end{array}$ & $\begin{array}{r}2.000 \\
(6.26)^{* * *}\end{array}$ & $\begin{array}{r}1.333 \\
(2.08)^{*}\end{array}$ \\
\hline Immigrant variables & & & & \\
\hline American citizenship & & & $\begin{array}{r}1.113 \\
(1.80)+\end{array}$ & $\begin{array}{r}.992 \\
(-.10)\end{array}$ \\
\hline Years in US & & & & $\begin{array}{r}.989 \\
(-3.13)^{* *}\end{array}$ \\
\hline Hire age & $\begin{array}{r}1.006 \\
(4.24)^{* * *}\end{array}$ & $\begin{array}{r}1.009 \\
(4.39)^{* * *}\end{array}$ & $\begin{array}{r}1.008 \\
(4.32)^{* * *}\end{array}$ & $\begin{array}{r}1.021 \\
(6.77)^{* * *}\end{array}$ \\
\hline Married & $\begin{array}{r}.824 \\
(-5.74)^{* * *}\end{array}$ & $\begin{array}{r}.816 \\
(-4.14)^{* * *}\end{array}$ & $\begin{array}{r}.814 \\
(-4.32)^{* * *}\end{array}$ & $\begin{array}{r}.788 \\
(-3.52)^{* * *}\end{array}$ \\
\hline Hourly & $\begin{array}{r}1.785 \\
(16.22)^{* * *}\end{array}$ & $\begin{array}{r}1.837 \\
(10.16)^{* * *}\end{array}$ & $\begin{array}{r}1.845 \\
(10.25)^{* * *}\end{array}$ & $\begin{array}{r}1.718 \\
(7.20)^{* * *}\end{array}$ \\
\hline Previous training & $\begin{array}{r}1.132 \\
(2.19)^{*}\end{array}$ & $\begin{array}{r}1.086 \\
(.95)\end{array}$ & $\begin{array}{r}1.081 \\
(.91)\end{array}$ & $\begin{array}{r}.943 \\
(-.53)\end{array}$ \\
\hline SEI & $\begin{array}{r}.965 \\
(-8.96)^{* * *}\end{array}$ & $\begin{array}{r}.955 \\
(-6.38)^{* * *}\end{array}$ & $\begin{array}{r}.955 \\
(-6.38)^{* * *}\end{array}$ & $\begin{array}{r}.962 \\
(-3.90)^{* * *}\end{array}$ \\
\hline SEI-squared & $\begin{array}{r}1.0004 \\
(6.63)^{* * *}\end{array}$ & $\begin{array}{r}1.001 \\
(3.78)^{* * *}\end{array}$ & $\begin{array}{r}1.001 \\
(3.77)^{* * *}\end{array}$ & $\begin{array}{l}1.0004 \\
(2.12)^{*}\end{array}$ \\
\hline Ambridge (factory) & $\begin{array}{r}.824 \\
(-4.35)^{* * * *}\end{array}$ & $\begin{array}{r}.671 \\
(-5.24)^{* * *}\end{array}$ & $\begin{array}{r}.655 \\
(-5.56)^{* * *}\end{array}$ & $\begin{array}{r}.639 \\
(-4.82)^{* * *}\end{array}$ \\
\hline Unemployment & $\begin{array}{r}.981 \\
(-9.65)^{* * * *}\end{array}$ & $\begin{array}{r}.975 \\
(-6.27)^{* * *}\end{array}$ & $\begin{array}{r}.975 \\
(-6.23)^{* * *}\end{array}$ & $\begin{array}{r}.992 \\
(-2.08)^{*}\end{array}$ \\
\hline WWI & $\begin{array}{r}.926 \\
(-1.74)+\end{array}$ & $\begin{array}{r}.828 \\
(-3.48)^{* *}\end{array}$ & $\begin{array}{r}.827 \\
(-3.51)^{* * *}\end{array}$ & $\begin{array}{r}.372 \\
(-6.19)^{* * *}\end{array}$ \\
\hline WWII & $\begin{array}{r}.729 \\
(-6.75)^{* * *} \\
\end{array}$ & $\begin{array}{r}.515 \\
(-6.57)^{* * *} \\
\end{array}$ & $\begin{array}{r}.510 \\
(-6.67)^{* * *}\end{array}$ & $\begin{array}{r}.565 \\
(-5.38)^{* * * *}\end{array}$ \\
\hline Log pseudolikelihood & $-45,390$ & $-16,622$ & $-16,620$ & $-7,969$ \\
\hline $\mathrm{AIC}$ & 90,820 & 33,279 & 33,277 & 15,976 \\
\hline Number of failures & 5,547 & 2,314 & 2,314 & 1,218 \\
\hline Number of individuals & 6,221 & 2,337 & 2,337 & 1,009 \\
\hline
\end{tabular}


Table B3 continued: Pullman-Standard Manufacturing

\begin{tabular}{|c|c|c|c|c|}
\hline & \multirow{2}{*}{$\begin{array}{c}\text { Pooled Sample } \\
\text { Model (1) }\end{array}$} & \multicolumn{3}{|c|}{ Immigrant-only sample } \\
\hline & & Model (2) & Model (3) & Model (4) \\
\hline \multicolumn{5}{|c|}{ US-born white (reference) } \\
\hline \multirow[t]{2}{*}{ US-born black } & 1.184 & & & \\
\hline & $(2.89)^{* *}$ & & & \\
\hline \multirow[t]{2}{*}{ Swedish } & .664 & & & \\
\hline & $(-2.48)^{*}$ & & & \\
\hline \multirow[t]{2}{*}{ Italian } & 1.017 & 1.555 & 1.499 & 1.445 \\
\hline & $(.15)$ & $(2.42) *$ & $(2.15)^{*}$ & $(1.66)+$ \\
\hline \multirow[t]{2}{*}{ Slavic } & 1.001 & 1.609 & 1.588 & 1.497 \\
\hline & $(.01)$ & $(2.94) * *$ & $(2.72)^{* *}$ & $(2.34)^{*}$ \\
\hline \multirow{2}{*}{ Other ethnicity } & 1.124 & 1.864 & 1.874 & 1.825 \\
\hline & $(1.86)+$ & $(4.31)^{* * *}$ & $(4.06)^{* * *}$ & $(3.80)^{* * *}$ \\
\hline \multicolumn{5}{|l|}{ Immigrant variables } \\
\hline \multirow{2}{*}{ US citizen } & & & .841 & .816 \\
\hline & & & $(-1.91)+$ & $(-2.10)^{*}$ \\
\hline \multicolumn{2}{|l|}{ Years in the United } & & & 1.002 \\
\hline \multicolumn{2}{|l|}{ States } & & & $(.50)$ \\
\hline \multirow[t]{2}{*}{ Hire age } & 997 & 996 & .996 & .996 \\
\hline & $(-1.37)$ & $(-1.08)$ & $(-.97)$ & $(-.75)$ \\
\hline \multirow[t]{2}{*}{ Married } & .869 & .882 & .915 & 982 \\
\hline & $(-2.91)^{* *}$ & $(1.64)+$ & $(-1.15)$ & $(-.21)$ \\
\hline \multirow{2}{*}{ Previous training } & .932 & 1.107 & 1.132 & 1.216 \\
\hline & $(-1.09)$ & $(.76)$ & $(.92)$ & $(1.25)$ \\
\hline \multirow[t]{2}{*}{ Relative in the factory } & .807 & .772 & .816 & .807 \\
\hline & $(-3.33) * *$ & $(-2.65)^{* *}$ & $(-1.99)^{*}$ & $(-2.00)^{*}$ \\
\hline \multirow[t]{2}{*}{ SEI } & .994 & 977 & .979 & 967 \\
\hline & $(-.92)$ & $(-1.96)^{*}$ & $(-1.76)+$ & $(-3.05)^{* *}$ \\
\hline \multirow[t]{2}{*}{ SEI square } & 999 & .999 & .999 & 1.0001 \\
\hline & $(-1.45)$ & $(-.13)$ & $(-.23)$ & $(.56)$ \\
\hline \multirow{2}{*}{ Unemployment rate } & 1.006 & 1.014 & 1.015 & 1.019 \\
\hline & $(1.93)+$ & $(3.17)^{* *}$ & $(3.37)^{* *}$ & $(4.11)^{* * *}$ \\
\hline \multirow[t]{2}{*}{ WWI } & 1.129 & 1.064 & 1.058 & 1.081 \\
\hline & $(1.92)+$ & $(.74)$ & $(.68)$ & $(.90)$ \\
\hline \multirow[t]{2}{*}{ WWII } & 1.193 & 1.384 & 1.458 & 1.381 \\
\hline & $(3.05)^{* *}$ & $(2.33) *$ & $(2.49)^{*}$ & $(1.84)+$ \\
\hline Log pseudolikelihood & -21562 & -7446 & -7444 & -6159 \\
\hline AIC & 43152 & 14917 & 14913 & 12345 \\
\hline Number of failures & 2931 & 1167 & 1167 & 994 \\
\hline Number of individuals & 2383 & 773 & 773 & 639 \\
\hline
\end{tabular}

$+.05<\mathrm{p}<.1, * \mathrm{p}<.05, * * \mathrm{p}<.01, * * * \mathrm{p}<.001$ (two-tailed)

Note: Hazard ratios are reported with $z$-statistics in the parentheses. 


\section{References}

Abramitzky, Ran, Leah Boustan, and Katherine Eriksson. 2012. “Europe's Tired, Poor, Huddled Masses: Self-Selection and Economic Outcomes in the Age of Mass Migration." American Economic Review 102(5): 1832-1856.

Abramitzky, Ran, Leah Boustan, and Katherine Eriksson. 2013. "Have the Poor Always Been Less Likely to Migrate? Evidence from Inheritance Practices during the Age of Mass Migration." Journal of Development Economics 102: 2-14.

Abramitzky, Ran, Leah Boustan, and Katherine Eriksson. 2014. "A Nation of Immigrants: Assimilation and Economic Outcomes in the Age of Mass Migration." Journal of Political Economy 122(3): 467-506

Alba, Richard and Victor Nee. 2003. Remaking the Mainstream: Assimilation and Contemporary Immigration. Cambridge: Harvard University Press.

Althauser, Robert P. 1989. “Internal Labor Markets.” Annual Review of Sociology 15: 143-61.

Applebaum, Herbert. 1981. Royal Blue: The Culture of Construction Workers. New York: Holt, Rinehart, and Winston.

Bailey, Thomas and Roger Waldinger. 1991. "Primary, Secondary, and Enclave Labor Markets: A Training Systems Approach.” American Sociological Review 56(4): 432-445.

Baron, James N., and William T. Bielby. 1980. "Bringing the Firms Back In: Stratification, Segmentation, and the Organization of Work." American Sociological Review: 737-765

Barrett, James R. 1992. “Americanization from the Bottom Up: Immigration and the Remaking of the Working Class in the United States, 1880-1930.” The Journal of American History 79(3): 996-1020. 
Biavaschi, Costanza, Corrado Giulietti, and Zahra Siddique. 2013. "The Economic Payoff of Name Americanization.” IZA Discussion Paper Series No. 7725.

Bloemraad, Irene. 2006. "Citizenship Lessons from the Past: The Contours of Immigrant Naturalization in the Early $20^{\text {th }}$ Century.” Social Science Quarterly 87(5): 927-953.

Bodnar, John. 1977. Immigration and Industrialization: Ethnicity in an American Mill Town, 1870-1940. Pittsburgh: University of Pittsburgh Press.

Bodnar, John. 1985. The Transplanted. Bloomington: Indiana University Press.

Bodnar, John, Roger Simon, Michael P Veber. 1982. Lives of Their Own: Blacks, Italians, and Poles in Pittsburgh, 1900-1960. University of Illinois Press.

Bonacich, Edna. 1976. "Advanced Capitalism and Black/White Race Relations in the United States: A Split Labor Market Interpretation.” American Sociological Review 41(1): 3451.

Cain, Pamela S. and Donald Treiman. 1981. "The Dictionary of Occupational Titles as a Source of Occupational Data." American Sociological Review 46(3): 253-278.

Carter, Susan and Richard Sutch. 1998. "Historical Background to Current Immigration Issues." Pp. 289-366 in The Immigration Debate: Studies on the Economic, Demographic, and Fiscal Effects of Immigration edited by J.P. Smith and B. Edmonston. Washington DC: National Research Council.

Castilla, Emilio. 2008. "Gender, Race, and Meritocracy in Organizational Careers." American Journal of Sociology 113: 1479-1526.

Cohen, Yinon, and Jeffrey Pfeffer. 1986. "Organizational Hiring Standards.” Administrative Science Quarterly 31(1): 1-24. 
Conor, Dylan S. 2015. "The Cream of the Crop? Migrant Selectivity from Ireland during the Age of Mass Migration.” Paper Presented at the Population Association of America Meeting, San Diego, CA.

Davis, James J. 1921. The Iron Puddler: My Life in the Rolling Mills and What Came of it. Hardpress.net.

Doeringer, Peter. 1986. "Internal Labor Markets and Noncompeting Groups.” The American Economic Review 76(2): 48-52.

Doeringer, Peter B., and Michael J. Piore. 1971. Internal Labor Markets and Manpower Analysis. Boston, MA: Heath Lexington Books.

Elbaum, Bernard. 1984. "The Making and Shaping of Job and Pay Structures in the Iron and Steel Industry.” Pp. 71-108 in Internal Labor Markets edited by Paul Osterman.

Fernandez, Roberto M. and M. Lourdes Sosa. 2005. “Gendering the Job: Networks and Recruitment at a Call Center.” American Journal of Sociology 111(3): 859-904.

Fischer, Claude S. and Michael Hout. 2006. Century of Difference: How America Changed in the Last One Hundred Years. New York: Russell Sage Foundation.

Fligstein, Neil and Roberto M. Fernandez. 1988. "Worker Power, Firm Power, and the Structure of Labor Markets." The Sociological Quarterly 29(1) 5-28.

Foote, Christopher L., Warren C. Whatley, and Gavin Wright. 2003. “Arbitraging a Discriminatory Labor Market: Black Workers at the Ford Motor Company, 1918-1947.” Journal of Labor Economics 21(3): 493-532

Gerschenkron, Alexander. 1962. Economic Backwardness in Historical Perspectives. Cambridge: Harvard University Press. 
Hatton, Timothy, and Jeffery Williamson. 1998. The Age of Mass Migration: Causes and Economic Impact. Oxford: Oxford University Press.

Hirsch, Susan E. After the Strike: A Century of Labor Struggle at Pullman. U of Nebraska Press. Hirschman, Charles, and Elizabeth Mogford. 2009. "Immigration and the American Industrial Revolution from 1880 to 1920.” Social Science Research 38(4): 897-920.

Hutchinson, E. P. 1956. Immigrants and their Children. New York: Wiley.

Ingham, John N. 1991. Making Iron and Steel: Independent Mills in Pittsburgh, 1820 to 1920. Ohio State University Press.

Inglehart, Ronald and Wayne E. Baker. 2000. "Modernization, Cultural Change, and the Persistence of Traditional Values.” American Sociological Review 65(1): 19-51.

Jacoby, Sanford M. 1984. "The Development of Internal Labor Markets in American Manufacturing Firms.” Pp. 23-70 in Internal Labor Markets edited by Paul Osterman

Jacoby, Sanford M. 1997. Modern Manors: Welfare Capitalism Since the New Deal. Princeton: Princeton University Press.

Kimeldorf, Howard. 2013. "Worker Replacement Costs and Unionization Origins of the U.S. Labor Movement.” American Sociological Review 78(6): 1033-1062

Lane, A.T. 1987. Solidarity or Survival: American Labor and European Immigrants, 1830 1924. New York: Greenwood Press.

Lebergott, Stanley. 1964. Manpower in Economic Growth: The American Record since 1800. New York: McGraw-Hill Book Company.

Lichtenstein, Nelson. 2002 State of the Union: A Century of American Labor. Princeton, NJ: Princeton University Press. 
Lieberson, Stanley. 1980. A Piece of the Pie: Blacks and White Immigrants since 1880. Berkeley: University of California Press.

Lieberson, Stanley and Mary Waters. 1990. From Many Strands: Ethnic and Racial Groups in Contemporary America. New York: Russell Sage Foundation.

Loizides, Georgios Paris. 2007. “'Making Men’ at Ford: Ethnicity, Race, and Americanization During the Progressive Period.” Michigan Sociological Review 21: 109-148.

Massey, Douglas S., Rafael Alarcon, Jorge Durand, and Humberto Gonzalez. 1987. Return to Aztlan: The Social Process of International Migration from Western Mexico. Berkeley: University of California Press.

Milkman, Ruth. 1987. Gender at Work: The Dynamics of Job Segregation by Sex during World War II. Urbana: University of Illinois Press.

Morawska, Ewa. 1985. For Bread with Butter. New York: Cambridge University Press.

Nelson, Daniel. 1975. Managers and Workers: Origins of the New Factory System in the United States 1880-1920. Madison, WI: The University of Wisconsin Press.

Olzak, Susan. 1989. “Labor Unrest, Immigration, and Ethnic Conflict in Urban America, 1880 1914.” American Journal of Sociology 94: 1303-33.

Perlmann, Joel. 2005. Italians Then, Mexicans Now: Immigrant Origins and Second Generation Progress, 1890 to 2000. New York: Russell Sage Foundation.

Perlmann, Joel and Roger Waldinger. 1996. "Second Generation Decline? Children of Immigrants, Past and Present: A Reconsideration." International Migration Review 31(4): 893-922.

Petersen, Trond and Ishak Saporta. 2004. "The Opportunity Structure for Discrimination." American Journal of Sociology 109: 852-901. 
Petersen, Trond and Seymour Spilerman. 1990. "Job Quits from an Internal Labor Market." Pp. 69-95 in Event History Analysis in Life Course Research. Edited by Karl Ulrich Mayer and Nancy Brandon Tuma.

Piore, Michael. 1979. Birds of Passage: Migrant Labor and Industrial Societies. Cambridge: Cambridge University Press.

Portes, Alejandro and Ruben Rumbaut. 2001. Legacies: the story of the immigrant second generation. Berkeley: University of California Press.

Portes, Alejandro and Min Zhou. 1993. "The New Second Generation: Segmented Assimilation and its Variants among post-195 Immigrant Youth.” The Annals of the American Academy of Political Social Science. 530(1): 74-96.

Prentice, R. L., J.D. Kalbfleisch, A.V. Peterson Jr., N. Flournoy, V.T. Farewell and N.E. Breslow. 1978. "The Analysis of Failure Times in the Presence of Competing Risks." Biometrics 34(4): 541-554

Rosenfeld, Jake. 2014. What Unions No Longer Do. Cambridge: Harvard University Press. Santos, Michael W. 1984. "Iron Workers in a Steel Age: The Case of the A.M. Byers Company, 1900-1969.” Diss., Carnegie-Mellon University.

Shertzer, Allison. 2013. "Immigrant Group Size and Political Mobilization: Evidence from European Migration to the United States.” National Bureau of Economic Research Working Paper 18827

Spilerman, Seymour and Trond Petersen. 1999. "Organizational Structure, Determinants of Promotion, and Gender Differences in Attainment." Social Science Research 28(2): 203227 
Stinchcombe, Arthur. 1990. Information and Organizations. Berkeley: University of California Press.

Tichenor, Daniel J. 2002. Dividing Lines: The Politics of Immigration Control in America. Princeton: Princeton University Press.

Tilly, Charles. 1990. "Transplanted Networks" in Immigration Reconsidered: History, Sociology, Politics, ed. Virginia Yans-McLaughlin, Oxford: Oxford University Press. United States Bureau of the Census. 1950. Census of Population, 1950: Classified Index of Occupations and Industries. Washington.

United States Department of Labor and United States Employment Service. 1939. Dictionary of Occupational Titles Washington.

Waldinger, Roger. 2007. "Did Manufacturing Matter? The Experience of Yesterday's Second Generation: A Reassessment.” International Migration Review 41(1) 3-39.

Waldinger, Roger and Michael Lichter. 2003. How the Other Half Works: Immigration and the Social Organization of Labor. Berkeley: University of California Press.

Waters, Mary. 1990. Ethnic Options: Choosing Identities in America. Berkeley: University of California Press.

Whatley, Warren C., and Gavin Wright. 1995a. Employee Records of the A.M. Byers Company [Pennsylvania], 1916-1952. Ann Arbor, MI: Inter-university Consortium for Political and Social Research.

Whatley, Warren C., and Gavin Wright. 1995b. Employee Records of the Pullman Car Works [Calumet, Illinois], 1902-1948. Ann Arbor, MI: Inter-university Consortium for Political and Social Research. 
Whatley, Warren C., and Gavin Wright. 1995c. Employee Records of the Ford Motor Company [Detroit Area], 1918-1947. Ann Arbor, MI: Inter-university Consortium for Political and Social Research. 

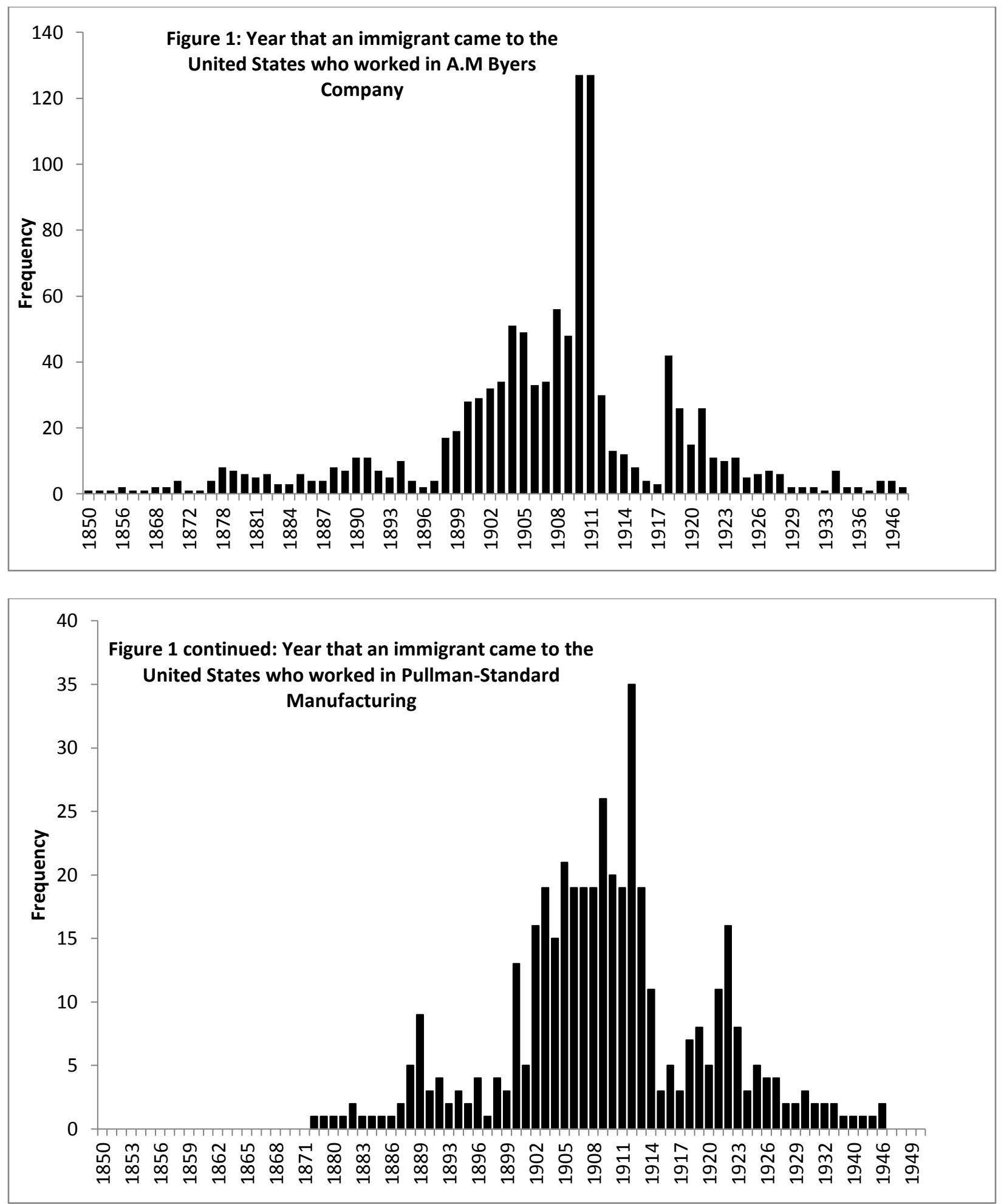

Note: Data come from the A.M. Byers and Pullman-Standard files. Frequencies broken down by ethnicity are available upon request. 
Figure 2: Average socioeconomic status (SEI) of men from selected immigrant groups by occupation number:

A.M. Byers Company

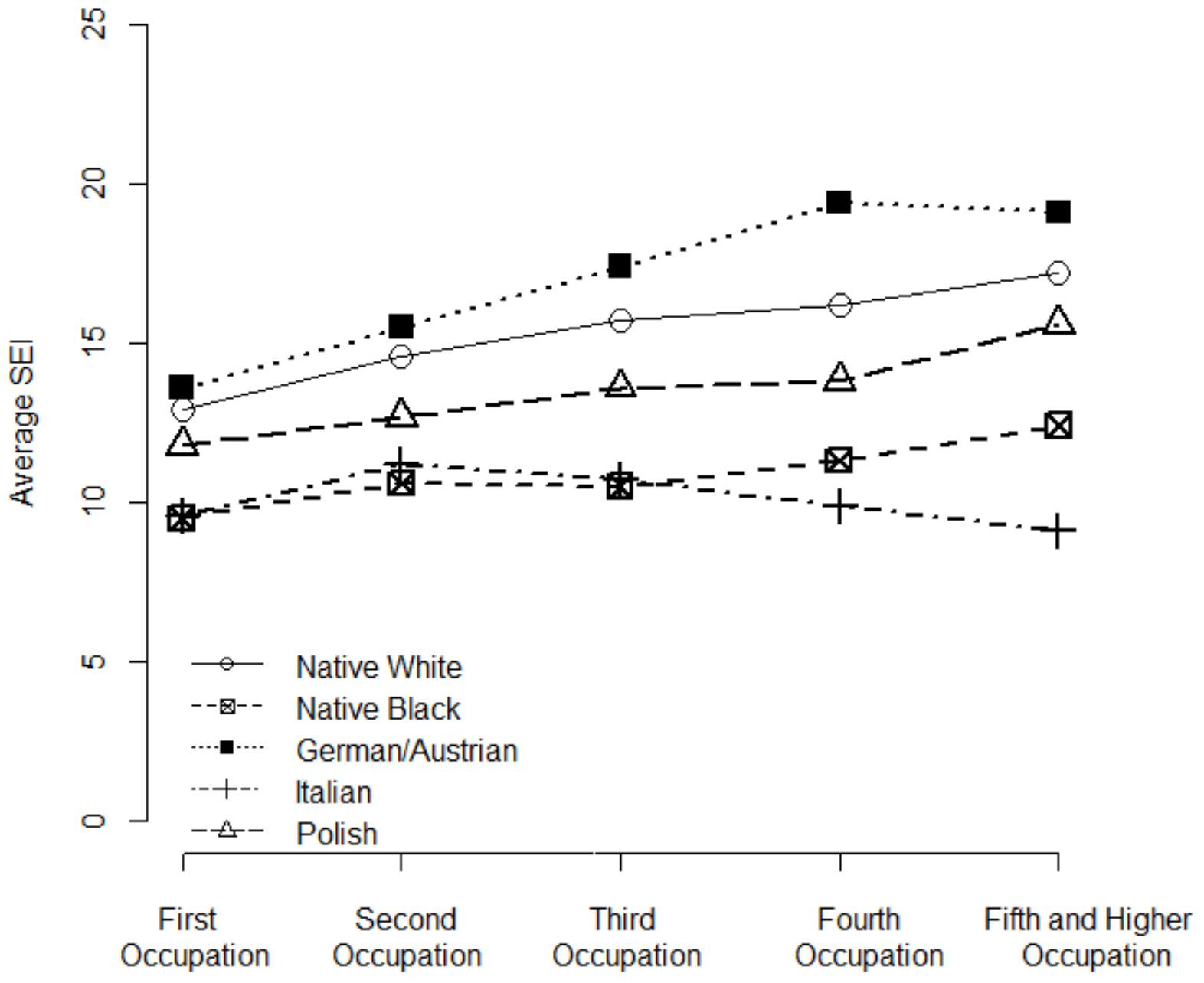


Figure 2 Continued:

Pullman-Standard Manufacturing

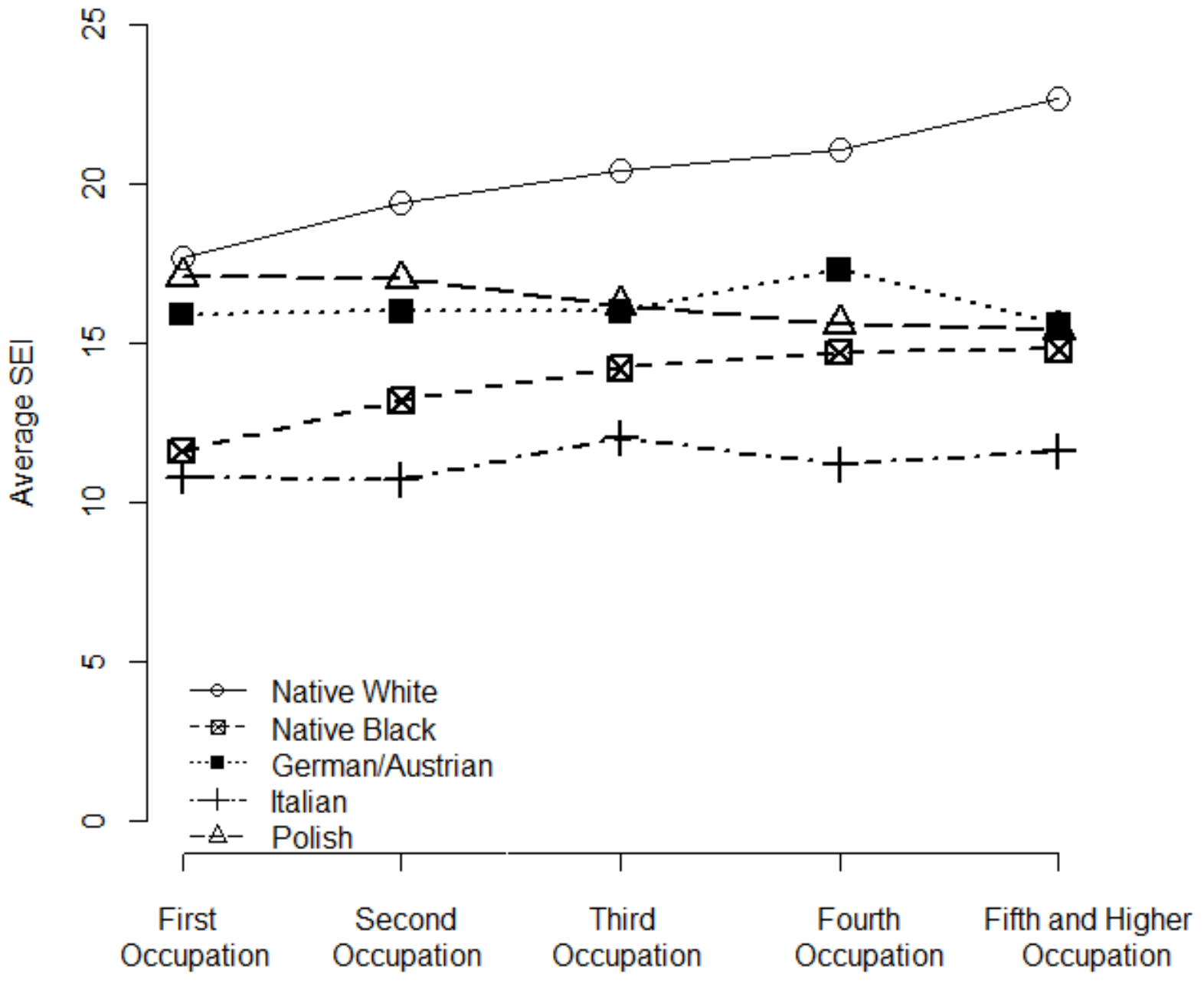


Figure 2 Continued:

Ford Motor Company

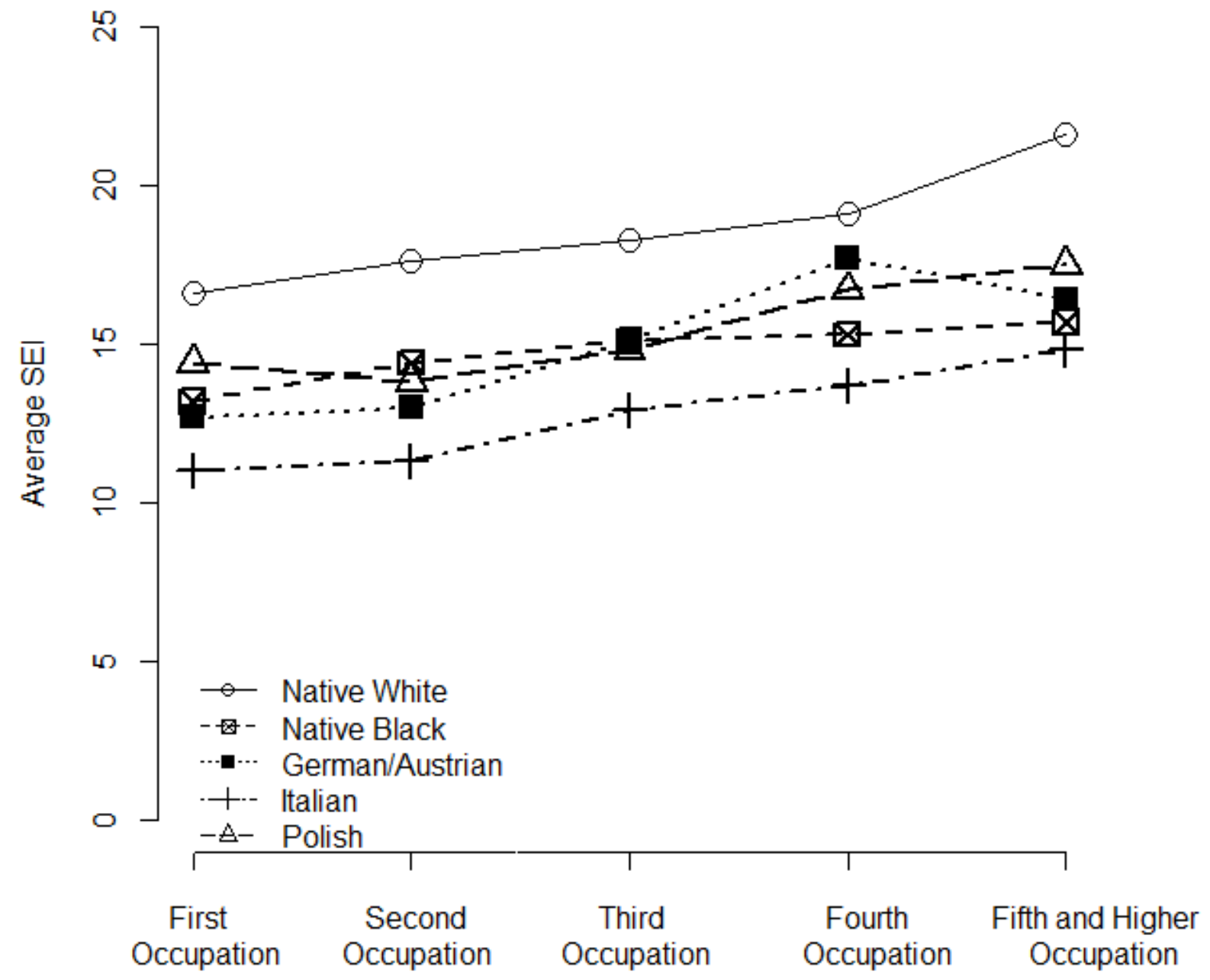

Note: Data come from the A.M. Byers, Pullman-Standard, and Ford Motor Company files matched to corresponding census data. See Appendix A for more details. First occupation refers to the occupation an individual has at initial hire. Second occupation refers to the next occupation after initial hire and so forth. 
Table 1: Sample of Worker Employment Histories from Byers, Pullman, and Ford

\begin{tabular}{|c|c|c|c|c|c|}
\hline \multicolumn{6}{|c|}{ A.M. Byers Company } \\
\hline $\begin{array}{c}\text { Employee \#: } \\
10670\end{array}$ & $\begin{array}{c}\text { Birthday: } \\
19 \text { April } 1890\end{array}$ & Hire Age: 30 & Sex: Male & $\begin{array}{l}\text { Marital Status: } \\
\text { Married }\end{array}$ & Dependents: 3 \\
\hline Education: - & Descent: Polish & $\begin{array}{l}\text { Citizenship: } \\
\text { American }\end{array}$ & $\begin{array}{l}\text { Birth State: } \\
\quad \text { Poland }\end{array}$ & Race: White & Plant: South \\
\hline Start & Finish & Occupation & Department & Wage & Exit Reason \\
\hline 24 June 1920 & 6 July 1920 & Laborer & \#4 Finish & $.46 /$ hour & - \\
\hline 6 July 1920 & 2 Sept. 1920 & Laborer & \#4 Weld & $.47 /$ hour & - \\
\hline 2 Sept. 1920 & 21 Sept. 1920 & Fagot Maker & Fagot & $.40 /$ hour & Quit - Better Job \\
\hline 20 July 1925 & 4 Jan. 1926 & Laborer & Scrap Hammer & $.40 /$ hour & Promoted* \\
\hline 4 Jan. 1926 & 27 Sept. 1926 & Scale Whlr & Muck Mill & .41 /hour & Promoted* \\
\hline 27 Sept. 1926 & 18 Feb. 1927 & Sand Whlr & Bar & $.37 /$ hour & $\begin{array}{c}\text { Quit - Small } \\
\text { Wages }\end{array}$ \\
\hline \multicolumn{6}{|c|}{ *Does not refer to promotion in occupational status as defined in my analyses below } \\
\hline \multicolumn{6}{|c|}{ Pullman-Standard Manufacturing } \\
\hline $\begin{array}{l}\text { Employee \#: } \\
21356\end{array}$ & $\begin{array}{c}\text { Birthday: } \\
\text { 1 March } 1922\end{array}$ & $\begin{array}{l}\text { Hire Age: } \\
20\end{array}$ & Sex: Male & $\begin{array}{l}\text { Marital Status: } \\
\text { Married }\end{array}$ & Dependents: 2 \\
\hline Education: 12 & $\begin{array}{l}\text { Descent: } \\
\text { Norwegian }\end{array}$ & $\begin{array}{l}\text { Citizenship: } \\
\text { American }\end{array}$ & $\begin{array}{l}\text { Birth State: } \\
\text { Oslo, Norway }\end{array}$ & Race: White & $\begin{array}{c}\text { Years in the US: } \\
11\end{array}$ \\
\hline Start & Finish & Occupation & Department & Wage & Exit Reason \\
\hline 1 May 1942 & 1 May 1942 & Metal Cleaner & Assembly & - & - \\
\hline 6 July 1942 & 10 Sept. 1942 & Student & Assembly & 60 & Transferred \\
\hline 11 Sept. 1942 & 29 Sept. 1942 & Riveter & Assembly & 63 & Changed Rate \\
\hline 30 Sept. 1942 & 31 Oct. 1942 & Riveter & Assembly & 75 & - \\
\hline 1 Nov. 1942 & 26 April 1943 & Riveter & Assembly & 75 & $\begin{array}{c}\text { Went into } \\
\text { Marine Corps }\end{array}$ \\
\hline \multicolumn{6}{|c|}{ Ford Motor Company } \\
\hline $\begin{array}{l}\text { Employee \#: } \\
\quad 3456\end{array}$ & $\begin{array}{c}\text { Birthday: } \\
\text { 10 March } 1898\end{array}$ & $\begin{array}{l}\text { Hire Age: } \\
\quad 45\end{array}$ & Sex: Male & $\begin{array}{l}\text { Marital Status: } \\
\text { Single }\end{array}$ & Dependents: 0 \\
\hline Education: 4 & $\begin{array}{l}\text { Descent: } \\
\text { Maltese }\end{array}$ & $\begin{array}{l}\text { Citizenship: } \\
\text { American }\end{array}$ & $\begin{array}{l}\text { Birth State: } \\
\quad \text { Malta }\end{array}$ & $\begin{array}{c}\text { Years in Detroit: } \\
.8333\end{array}$ & $\begin{array}{c}\text { Plant: Willow } \\
\text { Run }\end{array}$ \\
\hline Start & Finish & Occupation & Department & Wage & Exit Reason \\
\hline 28 April 1943 & 28 April 1943 & PRS OP TR & 930 & $.85 /$ hour & - \\
\hline 28 April 1943 & 4 June 1943 & Light PRS OP & 930 & 1.00/hour & - \\
\hline 4 June 1943 & 2 July 1943 & Light PRS OP & 930 & 1.05/hour & - \\
\hline 2 July 1943 & 5 Nov. 1943 & Light PRS OP & 930 & $1.10 /$ hour & - \\
\hline 5 Nov. 1943 & 9 Oct. 1944 & Light PRS OP & 930 & 1.15/hour & - \\
\hline 9 Oct. 1944 & 18 May 1945 & HY PRS OP & 927 & $1.20 /$ hour & Laid Off \\
\hline
\end{tabular}

Note: Employee did a good job 
Table 2: Occupational Moves as Events

\begin{tabular}{l|l}
\hline Rank & Types of Moves \\
\hline 1- Laborer & Internal Moves (rank change in employment of any size) \\
2- Operative & Laborer $\Leftrightarrow$ Operative \\
3- Craft worker & Operative $\Leftrightarrow$ Craft Worker \\
4- Managerial and professional & Craft Worker $\Leftrightarrow$ Managerial and Professional \\
& Laborer $\Leftrightarrow$ Craft Worker \\
Clerical and sales occupations excluded & Laborer $\Leftrightarrow$ Managerial and Professional \\
& Operative $\Leftrightarrow$ Managerial and Professional \\
& Exits (employee leaves the firm) \\
& Quit \\
& Other (layoff, fired, gone to war, retired, etc.) \\
\hline
\end{tabular}


Table 3: Number of job spells in each major occupational category by ethnicity

\begin{tabular}{|c|c|c|c|c|c|}
\hline \multicolumn{6}{|l|}{ Byers } \\
\hline & Laborer & Operative & Craft worker & $\begin{array}{l}\text { Managerial/ } \\
\text { professional }\end{array}$ & Total \\
\hline US white & 3,355 & 1,297 & 996 & 304 & 5,952 \\
\hline US black & 3,757 & 902 & 256 & 19 & 4,934 \\
\hline German/Austrian & 225 & 108 & 96 & 60 & 489 \\
\hline Italian & 404 & 47 & 26 & 1 & 478 \\
\hline Lithuanian & 215 & 121 & 33 & 9 & 378 \\
\hline Polish & 1,400 & 841 & 423 & 58 & 2,722 \\
\hline Russian & 260 & 69 & 20 & 0 & 349 \\
\hline Ruthanian & 442 & 229 & 54 & 1 & 726 \\
\hline Other Slavic & 595 & 311 & 140 & 7 & 1,053 \\
\hline Other Ethnicity & 1,413 & 344 & 393 & 53 & 2,203 \\
\hline Total & 12,066 & 4,269 & 2,437 & 512 & 19,284 \\
\hline \multicolumn{6}{|l|}{ Pullman } \\
\hline & Laborer & Operative & Craft worker & $\begin{array}{l}\text { Managerial/ } \\
\text { professional }\end{array}$ & Total \\
\hline US White & 853 & 2,088 & 1,036 & 546 & 4,523 \\
\hline US Black & 1,692 & 786 & 238 & 29 & 2,745 \\
\hline Swedish & 49 & 224 & 91 & 16 & 380 \\
\hline Italian & 279 & 72 & 33 & 0 & 384 \\
\hline Polish & 78 & 117 & 53 & 3 & 251 \\
\hline German/Austrian & 126 & 186 & 70 & 0 & 382 \\
\hline Slavic & 169 & 238 & 71 & 4 & 482 \\
\hline Other Ethnicity & 590 & 650 & 378 & 63 & 1,681 \\
\hline Total & 3,836 & 4,361 & 1,970 & 661 & 10,828 \\
\hline \multicolumn{6}{|l|}{ Ford } \\
\hline & Laborer & Operative & Craft worker & $\begin{array}{l}\text { Managerial/ } \\
\text { professional }\end{array}$ & Total \\
\hline US-born White & 1,799 & 3,301 & 1,289 & 539 & 6,928 \\
\hline US-born Black & 3,015 & 2,774 & 1,123 & 89 & 7,001 \\
\hline Canadian & 86 & 143 & 64 & 9 & 302 \\
\hline English & 112 & 85 & 43 & 18 & 258 \\
\hline German/Austrian & 48 & 45 & 38 & 0 & 131 \\
\hline Italian & 220 & 115 & 52 & 2 & 389 \\
\hline Polish & 211 & 219 & 86 & 0 & 516 \\
\hline Russian & 73 & 34 & 21 & 0 & 128 \\
\hline Other ethnicity & 701 & 657 & 253 & 65 & 1,676 \\
\hline Total & 6,265 & 7,373 & 2,969 & 722 & 17,329 \\
\hline
\end{tabular}


Table 4: Multinomial logistic regression predicting first occupation in the firm (laborer position is the baseline)

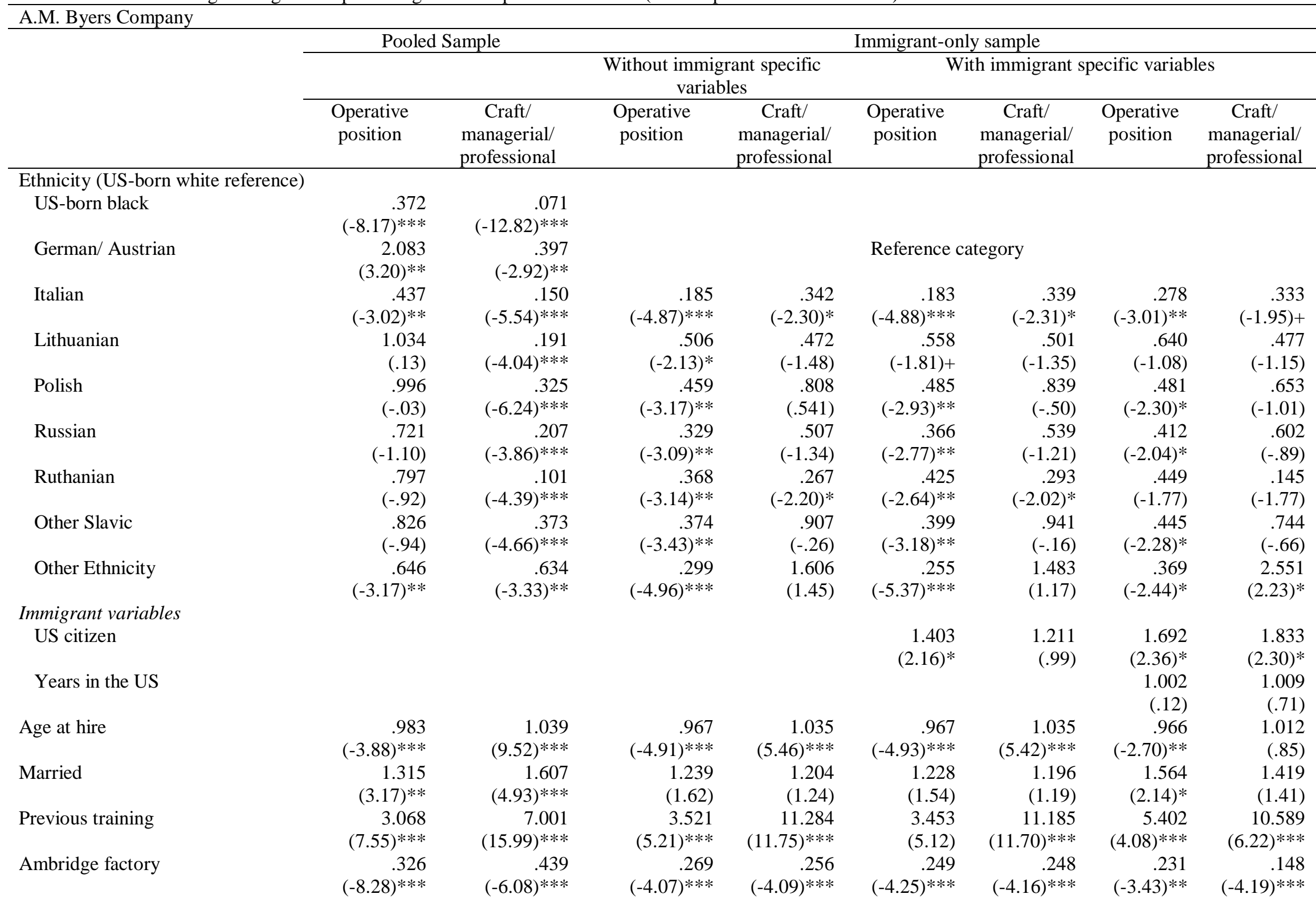


Table 4 continued

\begin{tabular}{|c|c|c|c|c|c|c|c|c|}
\hline \multicolumn{9}{|l|}{ A.M. Byers continued } \\
\hline & \multirow{2}{*}{\multicolumn{2}{|c|}{ Pooled Sample }} & \multicolumn{6}{|c|}{ Immigrant-only sample } \\
\hline & & & \multicolumn{2}{|c|}{$\begin{array}{l}\text { Without immigrant specific } \\
\text { variables }\end{array}$} & \multicolumn{4}{|c|}{ With immigrant specific variables } \\
\hline & $\begin{array}{l}\text { Operative } \\
\text { position }\end{array}$ & $\begin{array}{c}\text { Craft/ } \\
\text { managerial/ } \\
\text { professional }\end{array}$ & $\begin{array}{l}\text { Operative } \\
\text { position }\end{array}$ & $\begin{array}{c}\text { Craft/ } \\
\text { managerial/ } \\
\text { professional }\end{array}$ & $\begin{array}{l}\text { Operative } \\
\text { position }\end{array}$ & $\begin{array}{c}\text { Craft/ } \\
\text { managerial/ } \\
\text { professional }\end{array}$ & $\begin{array}{l}\text { Operative } \\
\text { position }\end{array}$ & $\begin{array}{c}\text { Craft/ } \\
\text { managerial/ } \\
\text { professional }\end{array}$ \\
\hline Unemployment rate in year of hire & $\begin{array}{l}1.009 \\
(1.31)\end{array}$ & $\begin{array}{r}1.006 \\
(.99)\end{array}$ & $\begin{array}{r}1.045 \\
(3.35)^{* *}\end{array}$ & $\begin{array}{r}1.039 \\
(2.67)^{* *}\end{array}$ & $\begin{array}{r}1.045 \\
(3.33)^{* *}\end{array}$ & $\begin{array}{r}1.039 \\
(2.66)^{* *}\end{array}$ & $\begin{array}{r}1.024 \\
(1.33)\end{array}$ & $\begin{array}{r}1.039 \\
(1.97)^{*}\end{array}$ \\
\hline Hired during WWI & $\begin{array}{r}.586 \\
(-4.52)^{* * * *}\end{array}$ & $\begin{array}{r}.695 \\
(-2.61)^{* *}\end{array}$ & $\begin{array}{r}.569 \\
(-3.90) * * *\end{array}$ & $\begin{array}{r}.574 \\
(-3.33)^{* *}\end{array}$ & $\begin{array}{r}.567 \\
(-3.91)^{* * * *}\end{array}$ & $\begin{array}{r}.571 \\
(-3.36) * *\end{array}$ & $\begin{array}{r}1.361 \\
(.97)\end{array}$ & $\begin{array}{r}1.769 \\
(1.39)\end{array}$ \\
\hline Hired during WWII & $\begin{array}{r}.411 \\
(5.86)^{* * * *} \\
\end{array}$ & $\begin{array}{r}.435 \\
(-5.73)^{* * *}\end{array}$ & $\begin{array}{r}.432 \\
(-1.88)+ \\
\end{array}$ & $\begin{array}{r}.534 \\
(-1.69)+ \\
\end{array}$ & $\begin{array}{r}.401 \\
(-2.04)^{*} \\
\end{array}$ & $\begin{array}{r}.517 \\
(-1.76)+ \\
\end{array}$ & $\begin{array}{r}.170 \\
(-2.65)^{* *}\end{array}$ & $\begin{array}{r}.794 \\
(-.50)\end{array}$ \\
\hline $\mathrm{N}$ & \multicolumn{2}{|c|}{6,559} & \multicolumn{2}{|c|}{2,465} & \multicolumn{2}{|c|}{2,465} & \multicolumn{2}{|r|}{1,034} \\
\hline Log-likelihood & \multicolumn{2}{|c|}{$-4,119$} & \multicolumn{2}{|c|}{$-1,671$} & \multicolumn{2}{|c|}{$-1,668$} & \multicolumn{2}{|r|}{-686} \\
\hline $\mathrm{BIC}$ & \multirow{2}{*}{\multicolumn{2}{|c|}{8,536}} & \multirow{2}{*}{\multicolumn{2}{|c|}{3,576}} & \multicolumn{2}{|c|}{3,587} & \multicolumn{2}{|r|}{1608} \\
\hline McFadden's R2 & & .13 & & .12 & \multicolumn{2}{|r|}{.12} & \multicolumn{2}{|r|}{.15} \\
\hline
\end{tabular}


Table 4: continued: Pullman-Standard Manufacturing

\begin{tabular}{|c|c|c|c|c|c|c|c|c|}
\hline & \multicolumn{2}{|c|}{ Pooled Sample } & \multicolumn{6}{|c|}{ Immigrant-only sample } \\
\hline & & & \multicolumn{3}{|c|}{ Without immigrant specific variables } & \multicolumn{3}{|c|}{ With immigrant specific variables } \\
\hline & $\begin{array}{l}\text { Operative } \\
\text { position }\end{array}$ & $\begin{array}{c}\text { Craft/ } \\
\text { managerial/ } \\
\text { professional }\end{array}$ & $\begin{array}{l}\text { Operative } \\
\text { position }\end{array}$ & $\begin{array}{c}\text { Craft/ } \\
\text { managerial/ } \\
\text { professional }\end{array}$ & $\begin{array}{l}\text { Operative } \\
\text { position }\end{array}$ & $\begin{array}{c}\text { Craft/ } \\
\text { managerial/ } \\
\text { professional }\end{array}$ & $\begin{array}{l}\text { Operative } \\
\text { position }\end{array}$ & $\begin{array}{c}\text { Craft/ } \\
\text { managerial/ } \\
\text { professional }\end{array}$ \\
\hline \multicolumn{9}{|l|}{ US-born white (reference) } \\
\hline US-born black & $\begin{array}{r}.192 \\
(-12.09) * * *\end{array}$ & $\begin{array}{r}.109 \\
(-12.50) * * *\end{array}$ & & & & & & \\
\hline Swedish & $\begin{array}{r}1.719 \\
(1.36)\end{array}$ & $\begin{array}{r}1.197 \\
(.40)\end{array}$ & \multicolumn{6}{|c|}{ Reference category } \\
\hline Italian & $\begin{array}{r}.111 \\
(-6.87)^{* * * *}\end{array}$ & $\begin{array}{r}.065 \\
(-5.72)^{* * * *}\end{array}$ & $\begin{array}{r}.064 \\
(-5.50)^{* * *}\end{array}$ & $\begin{array}{r}.058 \\
(-4.33) * * *\end{array}$ & $\begin{array}{r}.045 \\
(-5.09)^{* * * *}\end{array}$ & $\begin{array}{r}.036 \\
(-4.12)^{* * *}\end{array}$ & $\begin{array}{r}.038 \\
(-4.52)^{* * *}\end{array}$ & $\begin{array}{r}.023 \\
(-3.78) * * *\end{array}$ \\
\hline Polish & $\begin{array}{r}.897 \\
(-.33)\end{array}$ & $\begin{array}{r}.611 \\
(-1.26)\end{array}$ & $\begin{array}{r}.553 \\
(-1.17)\end{array}$ & $\begin{array}{r}.578 \\
(-.93)\end{array}$ & $\begin{array}{r}.597 \\
(-.77)\end{array}$ & $\begin{array}{r}.928 \\
(-.10)\end{array}$ & $\begin{array}{r}.463 \\
(-.91)\end{array}$ & $\begin{array}{r}.875 \\
(-.14)\end{array}$ \\
\hline German/ Austrian & $\begin{array}{r}.533 \\
(-2.16)^{*}\end{array}$ & $\begin{array}{r}.505 \\
(-2.07)^{*}\end{array}$ & $\begin{array}{r}.299 \\
(-2.51)^{*}\end{array}$ & $\begin{array}{r}.463 \\
(-1.40)\end{array}$ & $\begin{array}{r}.243 \\
(-2.51)^{*}\end{array}$ & $\begin{array}{r}.311 \\
(-1.80)\end{array}$ & $\begin{array}{r}.145 \\
(-2.82)^{* *}\end{array}$ & $\begin{array}{r}.197 \\
(-2.08)^{*}\end{array}$ \\
\hline Slavic & $\begin{array}{r}.322 \\
(-4.45)^{* * *}\end{array}$ & $\begin{array}{r}.355 \\
(-3.63)^{* * *}\end{array}$ & $\begin{array}{r}.198 \\
(-3.53)^{* * *}\end{array}$ & $\begin{array}{r}.349 \\
(-2.01)^{*}\end{array}$ & $\begin{array}{r}.166 \\
(-3.34)^{* *}\end{array}$ & $\begin{array}{r}.197 \\
(-2.59) *\end{array}$ & $\begin{array}{r}.123 \\
(-3.20)^{* *}\end{array}$ & $\begin{array}{r}.122 \\
(-2.70)^{* *}\end{array}$ \\
\hline Other Ethnicity & $\begin{array}{r}.368 \\
(-6.58) * * *\end{array}$ & $\begin{array}{r}.422 \\
(-5.15)^{* * * *}\end{array}$ & $\begin{array}{r}.212 \\
(-3.77)^{* * * *}\end{array}$ & $\begin{array}{r}.389 \\
(-2.01)^{*}\end{array}$ & $\begin{array}{r}.132 \\
(-3.89) * * *\end{array}$ & $\begin{array}{r}.421 \\
(-1.53)\end{array}$ & $\begin{array}{r}.078 \\
(-3.95) * * *\end{array}$ & $\begin{array}{r}.277 \\
(-1.82)+\end{array}$ \\
\hline US citizen & & & & & $\begin{array}{r}2.029 \\
(2.33)^{*}\end{array}$ & $\begin{array}{r}1.784 \\
(1.78)+\end{array}$ & $\begin{array}{r}1.172 \\
(.42)\end{array}$ & $\begin{array}{r}1.059 \\
(.14)\end{array}$ \\
\hline Years in the US & & & & & & & $\begin{array}{r}1.054 \\
(2.23)^{*}\end{array}$ & $\begin{array}{r}1.056 \\
(2.17)^{*}\end{array}$ \\
\hline Age at hire & $\begin{array}{r}1.018 \\
(2.81)^{* *}\end{array}$ & $\begin{array}{r}1.028 \\
(3.90)^{* * * *}\end{array}$ & $\begin{array}{r}1.027 \\
(2.30)^{*}\end{array}$ & $\begin{array}{r}1.033 \\
(2.53)^{*}\end{array}$ & $\begin{array}{r}1.027 \\
(1.70)+\end{array}$ & $\begin{array}{r}1.028 \\
(1.68)+\end{array}$ & $\begin{array}{r}.996 \\
(-.17)\end{array}$ & $\begin{array}{r}.998 \\
(-.07)\end{array}$ \\
\hline Married & $\begin{array}{r}1.182 \\
(1.47)\end{array}$ & $\begin{array}{r}1.175 \\
(1.21)\end{array}$ & $\begin{array}{r}1.219 \\
(1.01)\end{array}$ & $\begin{array}{r}1.175 \\
(.71)\end{array}$ & $\begin{array}{r}1.586 \\
(1.57)\end{array}$ & $\begin{array}{r}1.882 \\
(1.94)+\end{array}$ & $\begin{array}{r}2.292 \\
(2.46)^{*}\end{array}$ & $\begin{array}{r}2.911 \\
(2.73)^{* *}\end{array}$ \\
\hline Previous training & $\begin{array}{r}1.759 \\
(3.32)^{* *}\end{array}$ & $\begin{array}{r}2.382 \\
(4.68)^{* * *}\end{array}$ & $\begin{array}{l}1.569 \\
(1.20)\end{array}$ & $\begin{array}{r}3.712 \\
(32.54) * * *\end{array}$ & $\begin{array}{l}1.577 \\
(1.04)\end{array}$ & $\begin{array}{r}4.598 \\
(3.60) * * *\end{array}$ & $\begin{array}{r}2.852 \\
(1.85)+\end{array}$ & $\begin{array}{r}8.575 \\
(3.74)^{* * *}\end{array}$ \\
\hline Relative in the factory & $\begin{array}{r}.683 \\
(-2.04)^{*}\end{array}$ & $\begin{array}{r}.886 \\
(-.59)\end{array}$ & $\begin{array}{r}1.181 \\
(.44)\end{array}$ & $\begin{array}{r}1.959 \\
(1.74)+\end{array}$ & $\begin{array}{r}1.599 \\
(.96)\end{array}$ & $\begin{array}{r}1.604 \\
(.92)\end{array}$ & $\begin{array}{r}1.225 \\
(.39)\end{array}$ & $\begin{array}{r}1.150 \\
(.25)\end{array}$ \\
\hline $\begin{array}{l}\text { Unemployment rate at time } \\
\text { of hire }\end{array}$ & $\begin{array}{r}1.007 \\
(.59)\end{array}$ & $\begin{array}{l}1.016 \\
(1.33)\end{array}$ & $\begin{array}{r}1.051 \\
(2.13)^{*}\end{array}$ & $\begin{array}{r}1.053 \\
(2.19)^{*}\end{array}$ & $\begin{array}{l}1.041 \\
(1.59)\end{array}$ & $\begin{array}{l}1.037 \\
(1.34)\end{array}$ & $\begin{array}{l}1.044 \\
(1.36)\end{array}$ & $\begin{array}{r}1.044 \\
(1.24)\end{array}$ \\
\hline WWI & $\begin{array}{r}.160 \\
(-5.39)^{* * *}\end{array}$ & $\begin{array}{r}.748 \\
(-1.04)\end{array}$ & $\begin{array}{r}2.949 \\
(1.75)+\end{array}$ & $\begin{array}{r}2.006 \\
(.91)\end{array}$ & $\begin{array}{l}2.509 \\
(1.10)\end{array}$ & $\begin{array}{l}2.579 \\
(1.11)\end{array}$ & $\begin{array}{l}2.967 \\
(1.19)\end{array}$ & $\begin{array}{l}3.317 \\
(1.29)\end{array}$ \\
\hline WWII & $\begin{array}{r}1.094 \\
(.57) \\
\end{array}$ & $\begin{array}{r}1.038 \\
(.20)\end{array}$ & $\begin{array}{r}3.334 \\
(2.31)^{*}\end{array}$ & $\begin{array}{r}4.132 \\
(2.64)^{* *}\end{array}$ & $\begin{array}{l}2.636 \\
(1.70)\end{array}$ & $\begin{array}{r}2.394 \\
(1.50)\end{array}$ & $\begin{array}{r}1.622 \\
(.71)\end{array}$ & $\begin{array}{r}.816 \\
(-.28) \\
\end{array}$ \\
\hline $\mathrm{N}$ & & 2,413 & & 84 & & 415 & & 323 \\
\hline Log-likelihood & & -2201 & & 43 & & -368 & & -283 \\
\hline $\mathrm{BIC}$ & & 4637 & & 659 & & 904 & & 739 \\
\hline McFadden's R2 & & .12 & & 10 & & .17 & & .18 \\
\hline
\end{tabular}


Table 4 continued: Ford Motor Company

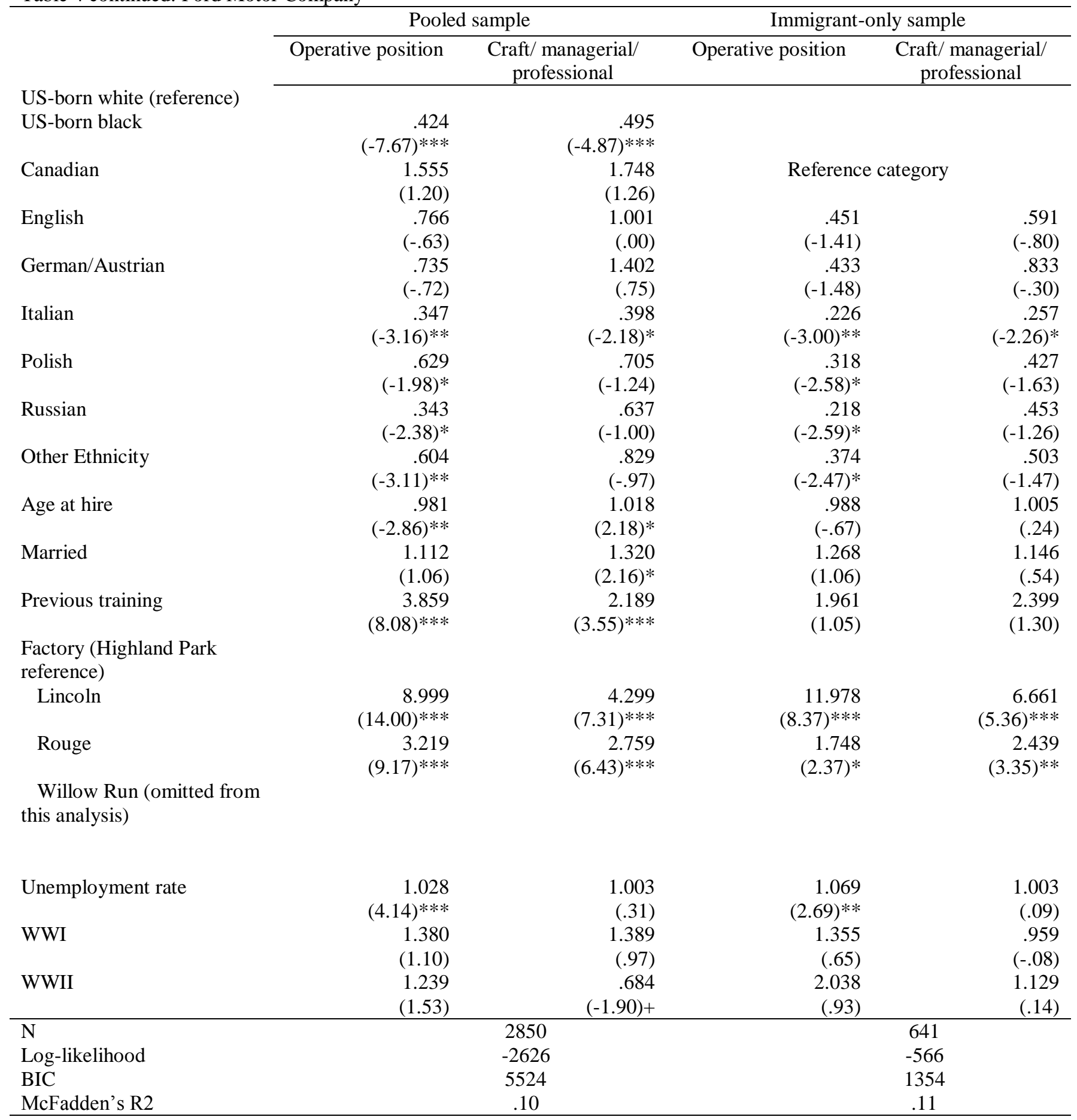

$+.05<\mathrm{p}<.1, * \mathrm{p}<.05, * * \mathrm{p}<.01, * * * \mathrm{p}<.001$ (two-tailed)

Note: Laborer position is the baseline. Odds ratio reported with z-statistic in the parentheses. 
Table 5: Types of occupational movements by ethnicity

\begin{tabular}{|c|c|c|c|c|c|c|}
\hline \multicolumn{7}{|c|}{ A.M. Byers Company } \\
\hline & $\begin{array}{c}\text { No. of } \\
\text { Individuals }\end{array}$ & $\begin{array}{l}\text { No. Job } \\
\text { Spells }\end{array}$ & $\begin{array}{c}\text { No. of } \\
\text { downward } \\
\text { moves }\end{array}$ & $\begin{array}{l}\text { No. of } \\
\text { upward } \\
\text { moves }\end{array}$ & No. of quits & $\begin{array}{l}\text { No. of other } \\
\text { exits }\end{array}$ \\
\hline US-born White & 2,450 & 4,082 & 197 & 463 & 1,569 & 1,853 \\
\hline US-born black & 1,434 & 2,973 & 208 & 343 & 1,033 & 1,389 \\
\hline German/Austrian & 121 & 210 & 10 & 29 & 72 & 99 \\
\hline Italian & 197 & 289 & 6 & 23 & 109 & 151 \\
\hline Lithuanian & 108 & 236 & 26 & 34 & 63 & 113 \\
\hline Polish & 501 & 1,264 & 110 & 179 & 375 & 600 \\
\hline Russian & 97 & 210 & 18 & 18 & 59 & 115 \\
\hline Ruthanian & 123 & 303 & 18 & 43 & 110 & 132 \\
\hline Other Slavic & 259 & 572 & 41 & 74 & 137 & 320 \\
\hline Other Ethnicity & 931 & 1,471 & 49 & 86 & 533 & 803 \\
\hline Total & 6,221 & 11,610 & 683 & 1,292 & 4,060 & 5,575 \\
\hline \multicolumn{7}{|c|}{ Pullman-Standard Manufacturing } \\
\hline & $\begin{array}{c}\text { No. of } \\
\text { Individuals }\end{array}$ & $\begin{array}{l}\text { No. Job } \\
\text { Spells }\end{array}$ & $\begin{array}{c}\text { No. of } \\
\text { downward } \\
\text { moves }\end{array}$ & $\begin{array}{l}\text { No. of } \\
\text { upward } \\
\text { moves }\end{array}$ & No. of quits & $\begin{array}{l}\text { No. of other } \\
\text { exits }\end{array}$ \\
\hline US-born White & 1,172 & 2255 & 120 & 262 & 648 & 1,225 \\
\hline US-born Black & 955 & 1,577 & 46 & 126 & 483 & 922 \\
\hline Swedish & 72 & 242 & 14 & 27 & 61 & 140 \\
\hline Italian & 114 & 252 & 6 & 23 & 59 & 164 \\
\hline Polish & 76 & 150 & 4 & 8 & 38 & 100 \\
\hline German/Austrian & 93 & 239 & 8 & 14 & 51 & 166 \\
\hline Slavic & 127 & 322 & 3 & 19 & 83 & 217 \\
\hline Other Ethnicity & 491 & 1,055 & 52 & 72 & 238 & 693 \\
\hline Total & 3,100 & 6,092 & 253 & 551 & 1,661 & 3,627 \\
\hline \multicolumn{7}{|c|}{ Ford Motor Company } \\
\hline & $\begin{array}{c}\text { No. of } \\
\text { Individuals }\end{array}$ & $\begin{array}{c}\text { No. Job } \\
\text { Spells }\end{array}$ & $\begin{array}{c}\text { No. of } \\
\text { downward } \\
\text { moves }\end{array}$ & $\begin{array}{l}\text { No. of } \\
\text { upward } \\
\text { moves }\end{array}$ & No. of quits & $\begin{array}{l}\text { No. of other } \\
\text { exits }\end{array}$ \\
\hline US-born White & 1,395 & 2,029 & 158 & 321 & 1,109 & 441 \\
\hline US-born Black & 1,102 & 1,876 & 211 & 374 & 772 & 519 \\
\hline Canadian & 47 & 75 & 9 & 13 & 37 & 16 \\
\hline English & 36 & 78 & 9 & 19 & 25 & 15 \\
\hline German/Austrian & 34 & 45 & 1 & 6 & 28 & 10 \\
\hline Italian & 71 & 112 & 8 & 21 & 60 & 23 \\
\hline Polish & 124 & 163 & 8 & 17 & 95 & 43 \\
\hline Russian & 44 & 55 & 2 & 5 & 37 & 11 \\
\hline Other ethnicity & 310 & 465 & 50 & 73 & 230 & 112 \\
\hline Total & 3,163 & 4,898 & 456 & 849 & 2,393 & 1,190 \\
\hline
\end{tabular}


Table 5a: Number of upward occupational moves by decade

\begin{tabular}{|c|c|c|}
\hline & Immigrants & Native-born \\
\hline \multicolumn{3}{|l|}{ A.M. Byers Company } \\
\hline Before 1920 & 210 & 155 \\
\hline 1921-1930 & 211 & 331 \\
\hline $1931-1940$ & 23 & 64 \\
\hline After 1940 & 42 & 256 \\
\hline \multicolumn{3}{|c|}{ Pullman-Standard Manufacturing } \\
\hline Before 1920 & 92 & 67 \\
\hline 1921-1930 & 25 & 31 \\
\hline 1931-1940 & 14 & 26 \\
\hline After 1940 & 32 & 264 \\
\hline \multicolumn{3}{|l|}{ Ford Motor Company } \\
\hline Before 1920 & 21 & 46 \\
\hline 1921-1930 & 109 & 304 \\
\hline 1931-1940 & 8 & 81 \\
\hline After 1940 & 16 & 264 \\
\hline
\end{tabular}


Table 6: Competing risk Cox-proportional hazard model predicting upward moves among nonmanagerial/professional occupations: A.M. Byers Company

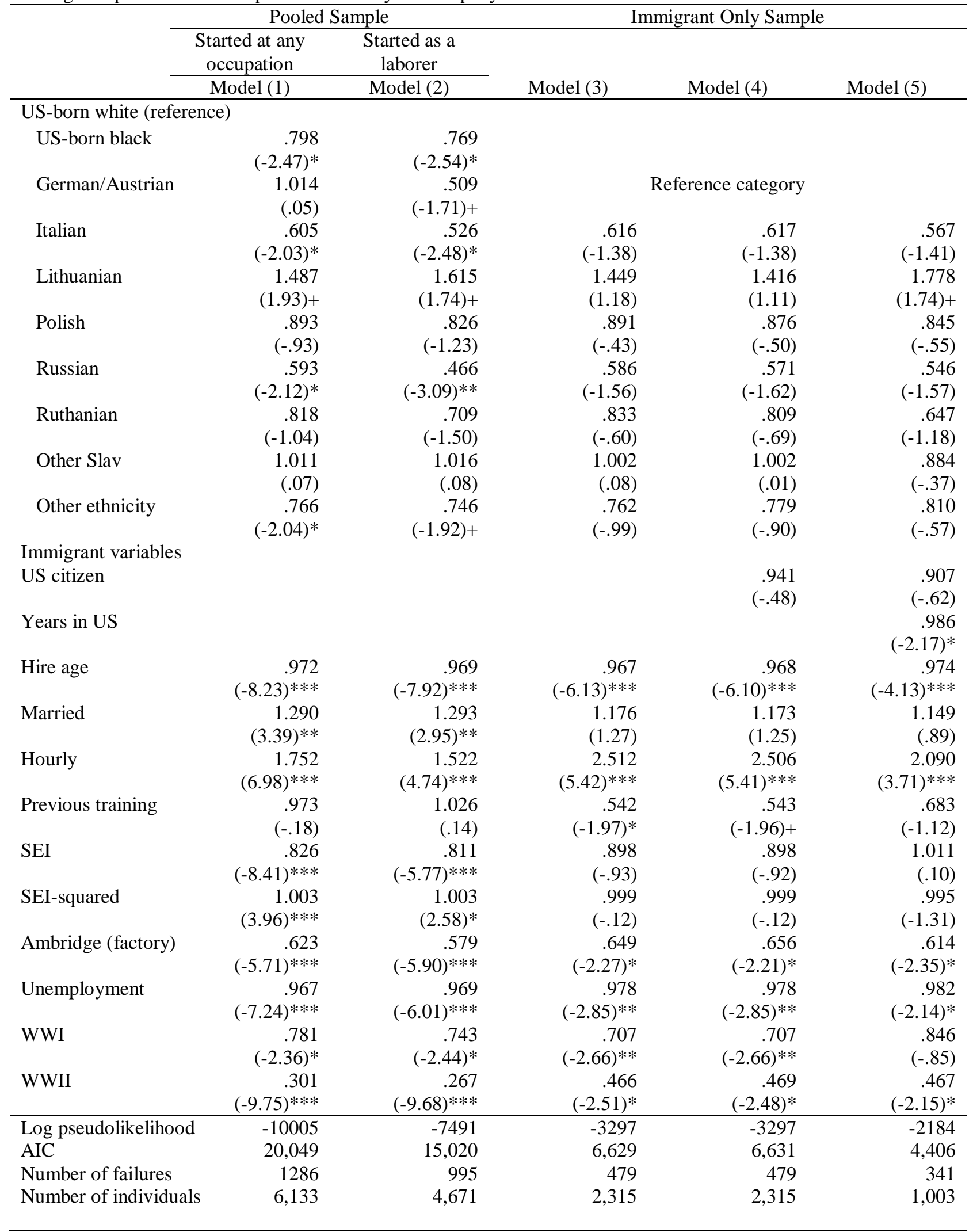


Table 6 continued: Pullman-Standard Manufacturing

\begin{tabular}{|c|c|c|c|c|c|}
\hline & \multicolumn{2}{|c|}{ Pooled Sample } & \multicolumn{3}{|c|}{ Immigrant Only Sample } \\
\hline & $\begin{array}{l}\text { Started at any } \\
\text { occupation }\end{array}$ & $\begin{array}{c}\text { Started as a } \\
\text { laborer }\end{array}$ & & & \\
\hline & Model (1) & Model (2) & Model (3) & Model (4) & Model (5) \\
\hline \multicolumn{6}{|c|}{ US-born white (reference) } \\
\hline US-born black & $\begin{array}{r}.432 \\
(-5.93)^{* * *}\end{array}$ & $\begin{array}{r}.385 \\
(-5.13)^{* * *}\end{array}$ & & & \\
\hline Swedish & $\begin{array}{r}1.211 \\
(.62)\end{array}$ & $\begin{array}{r}3.393 \\
(2.44)^{*}\end{array}$ & & rence category & \\
\hline Italian & $\begin{array}{r}.239 \\
(-4.47)^{* * *}\end{array}$ & $\begin{array}{r}.212 \\
(-3.99)^{* * *}\end{array}$ & $\begin{array}{r}.184 \\
(-3.74)^{* * *}\end{array}$ & $\begin{array}{r}.198 \\
(-3.70)^{* * *}\end{array}$ & $\begin{array}{r}.262 \\
(-2.24)^{*}\end{array}$ \\
\hline Slavic & $\begin{array}{r}.523 \\
(-2.62)^{* *}\end{array}$ & $\begin{array}{r}.581 \\
(-1.48)\end{array}$ & $\begin{array}{r}.481 \\
(-2.17)^{*}\end{array}$ & $\begin{array}{r}.493 \\
(-2.06)^{*}\end{array}$ & $\begin{array}{r}.612 \\
(-1.23)\end{array}$ \\
\hline Other ethnicity & $\begin{array}{r}.566 \\
(-3.44)^{* *}\end{array}$ & $\begin{array}{r}.499 \\
(-2.51)^{*}\end{array}$ & $\begin{array}{r}.517 \\
(-2.32)^{*}\end{array}$ & $\begin{array}{r}.508 \\
(-2.39)^{*}\end{array}$ & $\begin{array}{r}.641 \\
(-1.35)\end{array}$ \\
\hline \multicolumn{6}{|l|}{ Immigrant variables } \\
\hline US citizen & & & & $\begin{array}{l}1.367 \\
(1.15)\end{array}$ & $\begin{array}{r}1.177 \\
(.50)\end{array}$ \\
\hline Years in the US & & & & & $\begin{array}{r}1.010 \\
(.63)\end{array}$ \\
\hline Hire age & $\begin{array}{r}.997 \\
(-.56)\end{array}$ & $\begin{array}{r}.995 \\
(-.58)\end{array}$ & $\begin{array}{l}1.014 \\
(1.11)\end{array}$ & $\begin{array}{r}1.013 \\
(1.09)\end{array}$ & $\begin{array}{r}1.0003 \\
(.02)\end{array}$ \\
\hline Married & $\begin{array}{r}1.426 \\
(3.05)^{* *}\end{array}$ & $\begin{array}{r}1.692 \\
(2.88)^{* *}\end{array}$ & $\begin{array}{r}1.613 \\
(2.13)^{*}\end{array}$ & $\begin{array}{r}1.523 \\
(1.81)+\end{array}$ & $\begin{array}{r}1.681 \\
(1.94)+\end{array}$ \\
\hline Previous training & $\begin{array}{r}.727 \\
(-2.08)^{*}\end{array}$ & $\begin{array}{r}.876 \\
(-.53)\end{array}$ & $\begin{array}{r}.946 \\
(-.14)\end{array}$ & $\begin{array}{r}.899 \\
(-.29)\end{array}$ & $\begin{array}{r}.758 \\
(-.66)\end{array}$ \\
\hline Relative in the factory & $\begin{array}{r}1.174 \\
(1.22)\end{array}$ & $\begin{array}{r}1.527 \\
(2.18)^{*}\end{array}$ & $\begin{array}{r}1.838 \\
(2.54)^{*}\end{array}$ & $\begin{array}{r}1.615 \\
(1.82)+\end{array}$ & $\begin{array}{r}1.708 \\
(1.79)+\end{array}$ \\
\hline SEI & $\begin{array}{r}.782 \\
(-6.29)^{* * *}\end{array}$ & $\begin{array}{r}.776 \\
(-2.99) * *\end{array}$ & $\begin{array}{r}.735 \\
(-3.81)^{* * *}\end{array}$ & $\begin{array}{r}.737 \\
(-3.74)^{* * *}\end{array}$ & $\begin{array}{r}.738 \\
(-3.66)^{* * *}\end{array}$ \\
\hline SEI square & $\begin{array}{r}1.004 \\
(3.87)^{* * *}\end{array}$ & $\begin{array}{r}1.004 \\
(1.58)\end{array}$ & $\begin{array}{r}1.005 \\
(2.44)^{*}\end{array}$ & $\begin{array}{r}1.005 \\
(2.37)^{*}\end{array}$ & $\begin{array}{r}1.005 \\
(2.37)^{*}\end{array}$ \\
\hline Unemployment rate & $\begin{array}{r}.967 \\
(-3.36)^{* *}\end{array}$ & $\begin{array}{r}.959 \\
(-3.01)^{* *}\end{array}$ & $\begin{array}{r}.977 \\
(-1.37)\end{array}$ & $\begin{array}{r}.976 \\
(-1.53)\end{array}$ & $\begin{array}{r}.969 \\
(-1.40)\end{array}$ \\
\hline WWI & $\begin{array}{r}1.798 \\
(3.92)^{* * *}\end{array}$ & $\begin{array}{r}3.029 \\
(5.55)^{* * *}\end{array}$ & $\begin{array}{r}2.003 \\
(2.90)^{* *}\end{array}$ & $\begin{array}{r}2.083 \\
(3.05)^{* *}\end{array}$ & $\begin{array}{r}2.396 \\
(3.20) * *\end{array}$ \\
\hline WWII & $\begin{array}{r}2.915 \\
(7.96)^{* * *}\end{array}$ & $\begin{array}{r}4.385 \\
(7.57)^{* * *}\end{array}$ & $\begin{array}{r}2.869 \\
(2.62)^{* *}\end{array}$ & $\begin{array}{r}2.769 \\
(2.63)^{* *}\end{array}$ & $\begin{array}{r}3.530 \\
(2.77) * *\end{array}$ \\
\hline Log pseudolikelihood & -3006 & -1258 & -678 & -669 & -492 \\
\hline $\mathrm{AIC}$ & 6039 & 2545 & 1378 & 1365 & 1012 \\
\hline Number of failures & 427 & 203 & 116 & 110 & 84 \\
\hline Number of individuals & 2,332 & 1,073 & 773 & 718 & 302 \\
\hline
\end{tabular}

$+.05<\mathrm{p}<.1, * \mathrm{p}<.05, * * \mathrm{p}<.01, * * * \mathrm{p}<.001$ (two-tailed)

Note: Hazard ratios are reported with $z$-statistics in the parentheses. 